\title{
KIŞ̧iLERIN HUZUR VE SÜKÛNUNU BOZMA SUÇU
}

\author{
The Crime of Deterioratiosn of Peace and Order
}

\section{Muharrem ÖZEN* \\ Atacan KÖKSAL ${ }^{* *}$}

\section{ÖZ}

Hukuk normları, insanların belirli bir düzen içinde yaşamalarını sağlamak maksadıyla konulmuş kurallardır. Bu kurallara uygun biçimde yaşamak toplumdaki bütün insanların ortak menfaatlerinin bir gereğidir. Şüphesiz ki bu ortak menfaatin içinde, yaşama hakkı, vücut dokunulmazlığ cinsel özgürlük, kişi hürriyeti ve bunlarla birlikte sayılabilecek birçok değer yer alır. Bilimin zamanla ilerlemesi, organizasyon ve işbölümü ilişkilerinin farklılaşması, toplum yaşamı ve insan ilişkilerinin de değişmesine neden olmuştur. İnsanlar bu değişimin pek çok nimetinden faydalansa da, oluşan bu yeni ortam, onların bedensel ve ruhsal dengesine belli ölçüde etki etmiştir. Yaşam hakkının sağlıklı biçimde sürdürülmesi bağlamında, kişilerin hem ruhsal hem de bedensel dengesini koruma altına almak amaciyla çeşitli normlara ihtiyaç duyulmuştur. Kişilerin huzur ve sükûnunu bozma suçu da bu amaçla 5237 sayılı Türk Ceza Kanunu'nun 123. maddesinde düzenlenmiştir.

Anahtar Kelimeler: Kişi hürriyeti, huzur, sükûn, gürültü, telefon etme, 1srar.

Makalenin Geliş Tarihi: 26.06.2019 Makalenin Kabul Tarihi: 10.09.2019

* Prof. Dr., Ankara Üniversitesi Hukuk Fakültesi Ceza ve Ceza Muhakemesi Hukuku Anabilim Dalı Başkan1, E-posta: ozen@law.ankara.edu.tr, ORCID: 0000-0002-8406-8269

** Ar. Gör., Ankara Üniversitesi Hukuk Fakültesi Ceza ve Ceza Muhakemesi Hukuku Anabilim Dalı Öğretim Elemanı, E-posta: atacan.koksal@yahoo.com, ORCID: 00000003-1880-5176 


\begin{abstract}
Norms of law are the rules that provide people to live in certain order. Living in accordance with these rules is a requirement of the common interests of all people in society. There is no doubt that within this common interests, the right to life, physical integrity, sexual freedom, right to liberty, and many other values that can be counted. The devolopment of sciences over time, differentiation of the division of labor relations has also changed the life of society and human relations. Although people benefit from many aspects of this change, this new environment has affected their physical and mental balance to a certain extent. In order to maintain the right to life properly, various norms were needed to protect both the mental and physical balance of the individuals. The crime of deterioration of peace and order is regulated in the Artical 123 of the Turkish Criminal Code for this purpose.
\end{abstract}

Key Words: Right to liberty, peace, order, noise, call, insistence.

\title{
I. GENEL OLARAK
}

Yaşam hakkı, Amerikan Bağımsızlık Bildirisi ile Fransız İnsan ve Yurttaş Hakları Bildirisi'nden bu yana evrensel olarak tanınan insan haklarının başında gelmektedir. Bu hak en temel insan hakkıdır. Yaşam hakk1 ayrıca bütün diğer insan haklarının da varlık şartıdır. ${ }^{1}$ Yaşam hakkı Avrupa İnsan Hakları Sözleşmesi m. 2/1'deki, "Her ferdin yaşama hakkı kanunun himayesi altındadır. Kanunun ölüm cezası ile cezalandırdı ̆̆ bir suçtan dolayı hakkında mahkemece hükmedilen bu cezanın infazı dışında hiç kimse kasten öldürülemez" hükmüyle de koruma altına alınmıştır. 1982 Anayasası m. 17/1'de, "Herkes, yaşama, maddi ve manevi varlığını koruma ve geliştirme hakkına sahiptir" şeklinde düzenlenen hükümle, bu hak Anayasal çerçevede koruma altına alınmıştır. Bu çalışma bakımından ise yaşam hakk1, huzurlu biçimde yaşam hakkını da kapsama aldığ 1 için önem taşımaktadır. ${ }^{2}$ Anayasa'nın yukarıda yer verilen 17. maddesi kişilerin maddi ve manevi varlığını koruma ve geliştirme hakkını ortaya koyarken; 56. maddesinde herkesin sağl1klı ve dengeli bir çevrede yaşama hakkı düzenlenmiştir.

Mustafa Erdoğan, İnsan Hakları Teorisi ve Hukuku, B. 1, Ankara 2007, s. 141.

2 Özlem Yenerer Çakmut, Kişilerin Huzur ve Sükûnunu Bozma ve Gürültüye Neden Olma Suçları, B. 1, İstanbul 2014, s. 6. 
Yaşam hakkına bağlı olarak, kişilerin huzurlu bir biçimde yaşamalarını koruma altına almak amaciyla uluslararası düzenlemelerde de pek çok hüküm mevcuttur. İHEB m. 28 'de, "Herkesin, işsu beyannamede derpiş edilen hak ve hürriyetlerin tan tatbikini sağlayacak bir sosyal ve milletlerarası nizama hakkı vardır" şeklindeki hüküm ile AIHS m. 8/1'de, "Her şahıs hususi ve ailevi hayatına, meskenine ve muhaberatına hürmet edilmesi hakkına maliktir” şeklindeki hüküm bu amaca yöneliktir.

Kişilerin huzurlu şekilde yaşamalarına ilişkin genel çerçeve bu şekilde çizilmiş; insanların bedensel ve ruhsal anlamda sağliklarının tehlikeye düşmesine neden olacak fiiller, hukuken korunan değerlerin ihlali sayılarak Türk Ceza Kanunu'nda suç olarak düzenlenmiştir. Bu bağlamda kişilerin huzur ve sükûnunu bozma suçu, 5237 sayılı Türk Ceza Kanunu'nun 2. kitabının, "Hürriyete Karşı Suçlar" başlığını taşıyan 7. bölümündeki 123. maddesinde yer almıştır. Söz konusu suç, "Sirf huzur ve sükûnunu bozmak maksadıyla bir kimseye ısrarla telefon edilmesi, gürültü yapılması ya da aynı maksatla hukuka aykırı başka bir davranışta bulunulması halinde, mağdurun şikâyeti üzerine faile üç aydan bir yıla kadar hapis cezası verilir" şeklinde düzenlenmiştir. Maddenin gerekçesi, ${ }^{3}$ "Madde belirli bağıml hareketlerle kişilerinin huzur ve sükûnlarının bozulması hususunda gösterilen çabaları cezalandırmaktadır. Suçun maddi unsuru, bir kimseye ısrarla, gece gündüz demeden telefon edilmesi veya ona karşı ısrarla gürültü yapılmasıdır. Örneğin, oturulan apartmanın alt veya üst katında sürekli olarak öteberi çalarak gürültü yapılması gibi. Ancak bu hareketlerin sırf mağdurun huzur ve sükûnunu bozmak maksadıyla yapılması gerekmektedir. Böylece madde, suçun oluşması için, özel bir maksatla hareket edilmesi şartını getirmektedir. Dikkat edilmelidir $k i$ bu suç tanımıyla cezalandırılan fiiller, kişilerin üzerinde uygulanacak maddi veya cebri bir müdahale niteliği taşımamaktadır. Bu suç tanımı ile kişilerin psikolojik, ruhsal sükûn içinde yaşamak hakk korunmaktadır. Yapılan etkinlikler sonucu mağdurun dengesi bozulduğu örneğin, ruhsal bir teşevvüşe uğradiğ hallerde ise, kasten yaralama suçu söz konusu olacakttr. Maddede düzenlenen suçun soruş̧urulması ve kovuşturulması, suçtan zarar görenin şikâyetine bağlıdır", şeklindedir.

35237 sayılı Türk Ceza Kanunu madde gerekçeleri için bkz. www.cezabb.adalet.gov.tr/mevzuat/maddegerekce.doc (04.04.2019) 


\section{SUÇUN HUKUKİ KONUSU}

Suçun hukuki konusu, suç tarafindan ihlal edilen hukuki varlık veya menfaattir. ${ }^{4}$ Suçların tasnifinde, hukuki konunun en önemli kriter olduğu dikkate alındığında, her suçun hukuki konusunun tespitinde, bu suçların kanunda düzenlendiği yer önem arz eder. Bu açıdan, "Hürriyete Karş1 Suçlar" bölümünde düzenlenen bu suç, en temelde kişi hürriyetini ihlal etmektedir.

Hürriyet kavramı, bireyin irade özgürlüğünü, yani iradesini etki altında kalmaksızın oluşturup, bu iradeye uygun olarak hareket edebilmesini içerir. ${ }^{5}$ Kişi hürriyetine karşı işlenen suçların bir kısmı, fertlerin hareket serbestisini ortadan kaldırır veya sınırlar. Örneğin, bir kimseyi kanunsuz hapsetmek gibi. $\mathrm{Bu}$ çeşit suçların "dış hürriyete karşı işlenen suçlar" şeklinde isimlendirilmesi doğru olur. Fakat öyle suçlar vardır ki, kişilerin şu veya bu yolda hareket etme serbestilerini fiili veya maddi şekilde tahdit etmeyebilir. Fakat onların iç hürriyetlerini, yani korkusuz karar verme hürriyetlerini sınırlayabilir. $\mathrm{Bu}$ türden suçları da "iç hürriyete karşı suçlar" olarak nitelendirmek isabetlidir. ${ }^{6}$

Kişinin korkudan ve endişeden uzak, ruhsal açıdan sulh ve sükûn içinde olma hakkı da iç hürriyete dahildir. Kişinin huzur ve sükûnunu bozmaya yönelik fiiller onu endişeli, kaygıll, huzursuz, güvensiz ve tedirgin bir psikolojik duruma sokar. Bu fiiller, kişinin korku ve endişeden uzak, güven duygusu, sulh ve huzur içinde olma hakkına zarar verir. Bu nedenle kişilerin huzur ve sükûnunu bozma suç tipi ile özellikle iç hürriyet koruma altına alınmaktadır. $^{7}$

Sonuç olarak suçun hukuki konusu, psikolojik ve ruhsal bakımdan bireylerin rahatsız edilmeden huzur ve sükûn içinde ve sağlıkla yaşama haklarıdır. ${ }^{8}$

4 Nevzat Toroslu, Ceza Hukuku Genel Kisım, B. 14, Ankara 2009, s. 92; Zeki Hafızoğulları - Muharrem Özen, Türk Ceza Hukuku Özel Hükümler Kişilere Karşı Suçlar, B. 5, Ankara 2016, s. 3.

5 Durmuş Tezcan - Mustafa Ruhan Erdem - Murat Önok, Teorik ve Pratik Ceza Özel Hukuku, B. 10, Ankara 2013, s. 385.

6 Faruk Erem, Türk Ceza Kanunu Şerhi Özel Hükümler, C. 2, B. 1, Ankara 1993, s. 1178.

7 Meral Ekici Şahin, "Kişilerin Huzur ve Sükûnunu Bozma Suçu (TCK m. 123)”, in. CHD, S. 23, 2013, s. 26.

8 Yenerer Çakmut, s. 52; Ümit Kocasakal, "Kişilerin Huzur ve Sükûnunu Bozma Suçu (TCK 123)", in. ABD., Y. 2015, S. 2, s. 115; Ersan Şen, Yeni Türk Ceza Kanunu 


\section{SUÇUN FAİLI}

Kişilerin huzur ve sükûnunu bozma suçu açısından fail, bir özellik arz etmemektedir. $\mathrm{Bu}$ açıdan herkes suçun faili olabilir.

Temyiz kudretine sahip olmayan bir akıl hastası veya küçük bir çocuk da bu suçun faili olabilir. Bu nedenle kişilerin huzur ve sükûnunu bozma suçu, ceza hukuku anlamında iradi hareket edebilme yeteneğine sahip herkes tarafından işlenebilir. ${ }^{9}$

\section{SUÇUN MAĞDURU}

Bu suçun mağduru, belirli ${ }^{10}$ veya belirlenebilir gerçek bir kişi olabilir. ${ }^{11}$ Önemle belirtilmelidir ki, söz konusu suçun mağduru olabilmek için sırf huzur ve sükûnu bozulsun diye kendisine fail tarafından israrla telefon edilen, gürültü yapılan veya hukuka aykırı bir başka davranışta bulunulan kişi olunması gerekir. ${ }^{12}$ Madde gerekçesinde de yer verildiği üzere, herhangi bir kimseyi hedef almadan gerçekleştirilen fiiller bu suça vücut vermeyecektir. $\mathrm{Bu}$ açıdan madde başlığı "kişilerin" huzur ve sükûnunu bozma şeklinde düzenlenmiş olsa da, suçun TCK'daki yeri ve madde metninde yer alan "bir kimse" ibaresi dikkate alındığında, kanaatimizce bu suçun mağduru muayyen bir gerçek kişidir. ${ }^{13} \mathrm{Bu}$ itibarla, örneğin, bir fabrikanın çıkardığı gürültü veya bir bankanın alarm sisteminin geceleri bozulması nedeniyle çıkardığı sesler belirli bir kişiye yönelmediğinden bu

Yorumu, C. 1, B. 1, İstanbul 2006, s. 519. Benzer görüşler için bkz. Hafizoğulları - Özen, Kişilere Karşı, s. 227; Ali Parlar - Muzaffer Hatipoğlu, Açıklamalı Yeni İçtihatlarla 5237 Sayılı Türk Ceza Kanunu Yorumu, C. 2, B. 3, Ankara 2010, s. 1933; Veli Özer Özbek - Mehmet Nihat Kanbur - Koray Doğan - Pınar Bacaksız - İker Tepe, Türk Ceza Hukuku Özel Hükümler, B. 5, Ankara 2013, s. 443; Osman Yaşar - Hasan Tahsin Gökcan - Mustafa Artuç, Yorumlu Uygulamalı Türk Ceza Kanunu, C. 3, B. 2, Ankara 2014, s. 4065; Recep Gülşen, "Kişilerin Huzur ve Sükûnunu Bozma Suçu”, in. Zirve Üniversitesi Hukuk Fakültesi Dergisi, S. 1, 2012, s. 7; Ahmet Gökcen, "Hürriyete Karşı Suçlar”, s. 35. Erişim: www.ceza-bb.adalet.gov.tr/makale/117.doc (04.04.2019)

9 Ekici Şahin, "Huzur ve Sükûnunu”, s. 27.

10 "Hükümlü Ahmet'in 18.06.2005 günü yapılan düğ̈̈n sirasında kurusılk tabanca ile ateş ettiği ... 123. maddede düzenlenen suçta, gürültü çıkartarak huzur ve sükunu bozma eyleminin belli bir kişiye yönelik olması şartı bulunduğundan ... olayımızdaki eylemin bu suçları ... oluşturmadığı ..." (Yargitay CGK. E. 2007/8-109, K. 2007/115, 29.05.2007) Erişim: http://www.kazanci.com/kho2/ibb/files/cgk-2007-8-109.htm (04.04.2019)

11 Yaşar - Gökcan - Artuç, s. 4066.

12 Yenerer Çakmut, s. 53.

13 Aynı yönde görüş için bkz. Kocasakal, s. 132. 
suça değil; TCK m. 183'te düzenlenen gürültüye neden olma suçu veya Kabahatler Kanunu m. 36'daki gürültü kabahatine vücut verebilecektir. ${ }^{14}$

Mağdur konusunda incelenmesi gereken bir diğer husus ise, bu suçta mağdurun kendisine karşı gerçekleştirilen fiilleri algılayabilmesinin aranıp aranmayacağıdır. $\mathrm{Bu}$ konuda doktrinde genel olarak kabul edilen görüş, mağdurun, öncelikle huzur ve sükûnunu bozmaya yönelik gerçekleştirilen eylemleri algılayabilme yeteneğinin olması gerektiği yönündedir. ${ }^{15}$ Örneğin, komada yatan bir hasta veya kendisine karş1 gerçekleştirilen fiili algılayamayacak kadar küçük olan bir çocuk veya algılama yeteneği olmayan bir akıl hastası bu suçun mağduru olamaz. ${ }^{16}$ Kanaatimizce de, kişilerin psikolojik ve ruhsal bakımdan rahatsız edilmeden yaşamalarını koruma altına alan bu suçta, hukuki konunun ihlali için mağdurun rahatsızlık verecek fiilleri algilaması gereklidir. $\mathrm{Bu}$ fiilleri algılayamayan kimseler bakımından, hukuki konunun tehlikeye düşürülmesi dahi mümkün olamayacağı için, suçun oluşmayacağ kabul edilmelidir.

\section{SUÇUN UNSURLARI}

\section{A. MADDİ UNSUR}

\section{Genel Olarak}

Maddede suçun fiil unsuru, "bir kimseye israrla; telefon edilmesi, gürültü yapılması ya da aynı maksatla hukuka aykırı başka bir davranışta bulunulması" şeklinde ifade edilmiştir. "Telefon etme", "gürültü yapma" ve "hukuka aykırı başka bir davranışta bulunma" fiilleri, bu suçu seçimlik hareketli bir suç haline getirir. ${ }^{17}$ Kanaatimizce hükümde yer alan "1srar" kavramı, tüm seçimlik hareketler yani telefon etme, gürültü yapma ve hukuka aykırı başka bir davranışta bulunma için aranmaktadır. Zira madde

14 Yaşar - Gökcan - Artuç, s. 4070. "Sanığın işlettiği balık restoranında yüksek sesle müzik yapılmasını sağlayarak çevreyi rahatsız etme şeklinde gerçekleșen eyleminin, TCK'nın 183/1. maddesinde düzenlenen gürültüye neden olma suçunu oluşturup oluşturmayacağ tartışlmadan, yasal ve yeterli olmayan gerekçe ile yazılı şekilde kişilerin huzur ve sükûnunu bozma suçundan hüküm kurulması ..." (Yargitay 4. CD. E. 2012/22266, K. 2013/1010, 22.01.2013) Aktaran: Yaşar - Gökcan - Artuç, s. 4070, dn. 2471.

${ }^{15}$ Kocasakal, s. 118.

${ }^{16}$ Ekici Şahin, "Huzur ve Sükûnunu”, s. 27.

17 Yenerer Çakmut, s. 54. 
hükmünde de "1srarla" ifadesi ile seçimlik hareketlerin noktalı virgülle ayrılması, 1srarın her üç hareket için de aranması gerektiği yönündeki görüşümüzü doğrular niteliktedir. Israrın tüm seçimlik hareketler için de aranması, suçu bağlı hareketli bir suç haline getirir. ${ }^{18}$

$\mathrm{Bu}$ suç, kişilerin yalnızca konutunda huzur, sükûn ve güven içinde yaşama haklarını değil; genel olarak huzur ve sükûn içinde olma haklarını koruma altına aldığından, TCK m. 116'da düzenlenmiş olan konut dokunulmazlığının ihlali suçuna göre daha geniş bir koruma alanına sahiptir. Gerçekten de konut dokunulmazlığının ihlali suçu, suç tipiyle koruma altına alınmış olan konut, işyeri veya bunların eklentilerine girilmesi veya buralardan çıkılmaması ile işlenebilirken; kişilerin huzur ve sükûnunu bozma suçu kişinin konutunda, işyerinde, sokakta, parkta, plajda veya başka bir yerde gerçekleştirilen fiillerle de işlenebilir. Bu nedenle kişilerin huzur ve sükûnunu bozma suçunda hukuki koruma alanı, konut dokunulmazlığının ihlali suçundan farklı olarak yalnızca kişinin konutu, işyeri ve bunlara ait eklentilerle sınırlı değildir. ${ }^{19}$

Gerçekleşmesi için hukuki konunun tehlikeye düşürülmesinin yeterli olduğu bu suçun soyut tehlike mi yoksa somut tehlike suçu mu olduğu tartışmalıdır. Bir görüş, söz konusu suçun soyut tehlike suçu olduğu yönündeyken $;^{20}$ bir başka görüş, gerçekleştirilen davranışın mağdurun huzur ve sükûnunu bozmaya elverişli olup olmadığının araştırılacağı, hatta bu noktada objektif elverişlilik kriterine başvurulacağg düşüncesinden hareketle suçun somut tehlike suçu olduğu yönündedir. ${ }^{21}$ Kanaatimizce, suçun soyut tehlike mi yoksa somut tehlike suçu mu olduğunun saptanması noktasında, seçimlik hareketlerde bir ayrıma gidilmesi gerekir. Bu açıdan, sırf bir başka kimsenin huzur ve sükûnunu bozmak maksadiyla telefon edilmesi veya gürültü yapılması halinde, mağdurun huzur ve sükûnunun gerçekten bozulup bozulmadığı araştırmasına girişilmeksizin bu suçun oluştuğu kabul edilmelidir. Zira bu seçimlik hareketlerin gerçekleşmesi halinde, mağdurun huzur ve sükûnunun bozulduğu varsayımı TCK'da ifade edildiğinden suçun bu iki hareketle işlenmesi halinde ortada bir soyut tehlike suçu vardır. Ancak

\footnotetext{
18 Özbek - Kanbur - Doğan - Bacaksız - Tepe, s. 443; Gülşen, s. 9; Kocasakal, s. 119.

Suçun serbest hareketli suç olduğu görüşü için bkz. Şen, s. 519.

${ }^{19}$ Ekici Şahin, "Huzur ve Sükûnunu”, s. 28.

${ }^{20}$ Ekici Şahin, "Huzur ve Sükûnunu”, s. 32.

${ }^{21}$ Yenerer Çakmut, s. 71; Kocasakal, s. 138.
} 
"hukuka aykırı başka bir davranışta bulunmak" suretiyle bu suçun işlenebilmesi için gerçekleştirilen davranışın, mağdurun huzur ve sükûnunu bozmaya elverişli olup olmadığ 1 araştırılmalıdır. Bu noktada, mağdurun kişilik özellikleri ile değil; objektif kriterle hareket edilerek, gerçekleştirilen davranışın mağdurun huzur ve sükûnunu bozmaya elverişli olup olmadığı araştırılmalıdır. ${ }^{22}$ Örneğin, komada hasta olarak yatan bir hastanın bulunduğu odaya huzur ve sükûnunu bozmak amaciyla lazer tutulması veya doğuştan işitme engeli olan bir kimsenin penceresinin camına tıklatılması hallerinde söz konusu davranışlarla hukuki konunun ihlal edilmesi mümkün olamayacağı için suçun da oluşmayacağı kabul edilmelidir. Bu çözümle "hukuka aykırı bir davranışta bulunmak" seçimlik hareketinin, cezai sorumluluğun sınırlarını belirsiz bir biçimde genişletmesinin önüne de geçilebilecektir.

Maddede yer alan seçimlik hareketlerin ihmali hareketle gerçekleştirilip gerçekleştirilemeyeceği tartışmalıdır. ${ }^{23}$ Kanaatimizce, "telefon etmek" seçimlik hareketi, niteliği gereği sadece icrai hareketle gerçekleştirilebilirken; "gürültü yapmak" seçimlik hareketi, hem icrai hem de ihmali biçimde gerçekleştirilebilir. Örneğin, bir kimsenin evinin önünde nara atılması icrai hareket iken; ses çıkaran köpeğini bilerek susturmayan hayvan bakıcısı ihmali hareketle gürültü yapmış olmaktadır. Aynı şekilde, "hukuka aykırı başka bir davranış" da hem icrai hem de ihmali biçimde

22 Aynı yönde görüş için bkz. Şen, s. 520.

23 Doktrinde bir görüş, Alman Ceza Kanunu'nun 13. maddesinde olduğu gibi, ihmali hareket neticesinde cezai sorumluluğu belirleyen genel bir normun düzenlenmemesi karşısında, ihmali hareketin kanunda açıkça cezalandırıldığı hallerde (Örneğin, TCK m. 83, 88, 94/5 gibi), failin cezai sorumluluğunun olabileceği yönündedir. Yani icrai hareketle işlenebilen bir suç, yalnızca kanun koyucu bunu açıkça düzenlediğinde, ihmali hareketle de işlenebilir. Öğretide bazı yazarlar, TCK m. 123'ün ihmali hareketle işlenebileceği konusunda açık bir düzenleme olmaması karşısında, bu suçun sadece icrai hareketlerle işlenebileceğini savunmaktadır. Bkz. Ekici Şahin, "Huzur ve Sükûnunu”, s. 35. "Ícrai değil de ihmali olduğu tespit edilen bir davranış, o davranışın açıkça kanunda cezalandırılması veya o davranışın kanunda düzenlenmiş bulunan bir icrai suç tipine denk görülmesi ve davranışı yapanın da garantör olması halinde, failin harekete geçmesinin mümkün ve beklenebilir olması ve suçun diğer objektif ve sübjektif unsurlarının gerçekleşmiş olması halinde cezalandirllır. Türk Hukuku'nda saf ihmali suçların kanunda düzenlenmiş bulunmaları, sorunun çözümü bakımından bir dayanak noktası sunmaktadır. Buna karşılık (garantörsel) ihmali suçlar bakımından aynı şey söylenemez. Nitelikli (garantörsel) ihmali suçlara ilişkin bir hüküm, Türk Hukuku'nda ihmali suçlar konusunda hiç olmayan ve eksikliği açık bulunan uygulamayı başlatacaktır." Bkz. Hakan Hakeri, Ceza Hukukunda İhmal Kavramı ve İhmali Suçların Çeşitleri, B. 1, Ankara 2003, s. 311-312. 
gerçekleştirilebilir. Mağdurun penceresine taş atan failin davranışı icrai hareket iken; alt katta oturan komşunun uyarılarına rağmen, su damlatan tuvalet borusunu tamir ettirmeyen üst kattaki kişinin davranışı ihmal biçimindedir.

\section{Israr Kavramı}

Israr, kelime anlamı itibariyle direnme, ayak direme, üsteleme, üstünde durma demektir. ${ }^{24}$ Kişilerin huzur ve sükûnunu bozma suçunun işlenebilmesi için davranışların 1srarla gerçekleştirilmesi zorunludur. Israr, kendi içinde sürekliliği de barındırmaktadır. Dolayısıyla madde metninde belirtilen seçimlik hareketlerin bir defa gerçekleştirilmesi, mağdurun huzur ve sükûnunu bozmuş olsa dahi suçun oluşması için yeterli değildir. ${ }^{25}$

TCK'da bir davranışın 1srarla yapıldığı sonucuna varılabilmesi için, kaç kez tekrarlanması gerektiğine ilişkin açık bir düzenleme bulunmamaktadır. Doktrinde, mağdurun rahatsızlığını ifade etmiş olmasına ve aynı veya benzer davranışların bir daha yapılmaması konusunda faili uyarmasına rağmen; failin gürültü yapmaya, telefon etmeye veya hukuka aykırı başka bir davranışta bulunmaya devam etmesi halinde ısrarın oluştuğu kabul edilmektedir. ${ }^{26}$

Yarg1 uygulamasinda da hareketlerin yalnızca bir defa gerçekleştirilmesi suçun oluşması bakımından yeterli görülmemektedir. ${ }^{27} \mathrm{Bu}$

24 Bkz. http://www.tdk.gov.tr (04.04.2019)

25 Yenerer Çakmut, s. 63. "Sanığın katılanlara ait telefonu olay gecesi bir kez arayarak, katılan Bilal ile görüşmesi şeklinde gerçekleşen eyleminde, TCK'nın 123. maddesinde düzenlenen kişilerin huzur ve sükûnunu bozma suçunun 'israr' unsurunun gerçekleşmediği ...” (Yargitay 4. CD. E. 2012/14281, K. 2013/3035, 06.02.2013) Aktaran: Yaşar Gökcan - Artuç, s. 4069, dn. 2467.

26 Ekici Şahin, "Huzur ve Sükûnunu", s. 39. Suçun itiyadi suç olduğunun benimsenmesi durumunda, itiyadı oluşturan hareketlerin aynı cinsten olması gerekliliğinden ötürü farklı seçimlik hareketlerin gerçekleştirilmesi halinde 1 srarın ve suçun oluşmayacağ savunulmuştur. Bu kabulde, üst katta oturan failin bir gün alttaki mağdurun ev telefonunu araması, ertesi gün ise gürültü yapması durumunda aynı cinsten hareketler gerçekleştirilmediğinden, suç da oluşmayacaktır. Bkz. Kocasakal, s. 144.

27 "Oluş ve dosya içeriğine göre, sanıklardan Şenol'un katılan sanık Yasemin'e yönelik duygusal ilgi sebebiyle olay günü sanıklar; Şenol, Ercan ve Aydın'ın katılan sanıklar Ali Ihsan, Yasemin, Ayşegül ve Nursel'in evlerinin yakınlarına gelip nara atarak olay yaratması şeklindeki eylemlerinin, ... ısrarla yapılmamış olması ve bu itibarla da 5237 sayılı TCK'nın 123. maddesinde düzenlenen kişilerin huzur ve sükununu bozmak suçunun, eylemin anlatılan șekliyle oluşmadığı gözetilmeden, sanıkların atılı suçtan beraatleri 
açıdan olayın oluş biçimi, tekrarlanma sıklığ $1{ }^{28}$ mağdurun yapılan davranışı yasaklayıp yasaklamadığı gibi ölçütlerden hareket edilmektedir. ${ }^{29}$ Ancak hareketlerin arasında çok uzun bir zaman fasılasının bulunması halinde, örneğin önceki bir defalığına müzik çalma eyleminden bir ay sonra bir defa telefonla aramak gibi, 1srar oluşmayabilir. ${ }^{30}$

Israrın ön şartı, kişinin karşı yönde oluşan iradesine bilinçli bir aykırılık teşkil eden davranışların yapılması veya karşı tarafın arzusuna kayıtsızlık ve onun menfaatlerini ihlal eden davranışları tekrarlamaktır. Yasaklanan davranışlar çok uzun olmayan zaman aralıklarıyla tekrarlandığında ve aralarında amaç birliği olduğunda israrla gerçekleştirildikleri kabul edilir. ${ }^{31}$ Burada, davranışların birden fazla gerçekleştirilmesi şart olmakla birlikte, en

yerine yazılı şekilde hüküm kurulması ...” (Yargitay 2. CD. E. 2009/13780, K. 2010/17821, 02.06.2010) Erişim: http://www.kazanci.com/kho2/ibb/files/2cd-200913780.htm (04.04.2019)

28 “Saniğı̆n olay gecesi Fatma T. ile haberleşmek için Fatma T. 'nin annesi olan katılanın cep telefonuna saat 23.59 ile 11.03 arasinda $32 \mathrm{kez}$ SMS göndermek suretiyle yüklenen kişilerin huzur ve sükûnunu bozma suçunu işlediği halde, yasal ve yeterli olmayan gerekçelerle beraat kararı verilmesi ..." (Yargitay 4. CD. E. 2012/28447, K. 2013/883, 21.01.2013) Aktaran: Yaşar - Gökcan - Artuç, s. 4079.

29 “Katılanlardan Aydın'ın ă̆abeyi, Habibe'nin ise kayınbiraderi Osman ile evli olan sanık Özlem'in, eşiyle aralarındaki ailevi sorunlar konusunda yardımcı olmaları amactyla katılanları aradığına ancak kendisi ile konuşmayarak telefonu kapattıklarına dair savunmasina dayanilarak beraatine karar verilmiş ise de; katılanların iddialarına ve getirilen telefon kayıtlarına göre, sanığın katılan Aydın'ın kullandı̆̆ cep telefonunu 25.08.2005 tarihinde $5 \mathrm{kez}, 27.08 .2005$ tarihinde $15 \mathrm{kez}$, katılan Habibe'nin telefonunu ise 25.08.2005 tarihinde $3 \mathrm{kez}, 26.08 .2005$ tarihinde $1 \mathrm{kez}, 27.08 .2005$ tarihinde $3 \mathrm{kez}$, 28.08.2005 tarihinde $2 \mathrm{kez}$ ve 04.09.2005 tarihinde $7 \mathrm{kez}$ aradlğ ve her iki katılana yönelik aramaların günün değişik saatlerinde ve sik aralıklarla gerçekleştiği, çoğu aramalarda taraflar arasında hiç görüşme yapılmadığ süreli görüşmelerin gerçekleştiği, katılanların kendisi ile görüşmek istemedikleri için telefonu kapattıklarını kabul eden sanığın ısrarla aramaya devam etmek suretiyle kişilerin huzur ve sükûnunu bozmak amacıyla hareket ettiği ve atılı suçun unsurlarının oluştuğu gözetilerek cezalandırılmasına karar verilmesi gerekirken; yazılı şekilde beraatine karar verilmesi ..." (Yargitay 2. CD. E. 2008/28340, K. 2009/29945, 22.06.2009) Erişim: http://www.kazanci.com/kho2/ibb/files/2cd-2008-28340.htm (04.04.2019)

30 Yaşar - Gökcan - Artuç, s. 4069.

31 "Müştekinin mücerret beyanı dışında, sanığın tehdit sözü sarf ettiği konusunda delil bulunmadĭ̆ halde, mahkemenin kabulüne göre de sanığın müstekiyi 1 ay zarfinda 80 defa araması müştekiyi rahatsı edici nitelikte bulunmuş olmasına göre eylemin bu haliyle TCK'nın 547. maddesi kapsamında değerlendirilmesi gerekeceği gözetilmeden yazılı şekilde unsurları bulunmayan sair tehdidat suçundan hüküm tesisi ..." (Yargıtay 2. CD. E. 2002/9624, K. 2003/11926, 09.10.2003) http://www.kazanci.com/kho2/ibb/files/2cd-2002-9624.htm (04.04.2019) 
az kaç kez tekrarlanması gerektiğine ilişkin bir sayı belirlemek mümkün değildir. Zira mağdurun ilk hareketten duyduğu rahatsızlığı dile getirip, faili hareketin tekrarından men ettiği hallerde, aynı veya benzer davranışın ikinci defa tekrarlanması 1srar unsurunu oluşturabilir. Örneğin, rahatsız etmek amacıyla yüksek sesle müzik çalan faile, mağdurun rahatsız olduğunu ifade etmesine rağmen failin bu hareketine devam etmesi durumunda israr gerçekleşmiş olur. ${ }^{32}$ Buna karşın başka bir olayda, üçüncü veya beşinci davranış ancak ısrar olarak değerlendirilebilir. Bu nedenle hareketlerin sayısı ve tekrarlanma sıklığına ilişkin genel geçer bir rakam belirlemek yerine, her somut olay kendi bağlamında değerlendirilerek ısrarın varlığı tespit edilmelidir. ${ }^{33}$

Seçimlik hareketlerin ısrarla gerçekleştirilmesinin arandığı bu suç tipinde 1srarın, suçu mütemadi bir suç haline getirip getirmediği doktrinde tartışma konusudur. Bir görüşteki yazarlar, davranışın 1srarla gerçekleştirilmesinin bu suçu mütemadi bir suç haline getirdiğini savunurken; ${ }^{34}$ diğer görüşteki yazarlar, 1 srarın bu suçu her zaman mütemadi bir suç haline getirmeyeceğini ileri sürmektedir. ${ }^{35}$ Doktrinde kabul edildiği üzere mütemadi suç, hareketten doğan neticenin derhal sona ermeyip, bir süre devam ettiği suç olarak tanımlanmaktadır. ${ }^{36}$ Buna göre, mütemadi suçta ihlal kesintisiz olup, hareket ve netice kesilmemekte; aynı ve tek bir netice devam etmektedir. ${ }^{37}$ Eğer kesinti meydana gelmişse normun ihlali ve suç sona erer. Kesintiden sonra, kanunda öngörülen hareketlerin icrasına yeniden başlanırsa, bu ikinci hareket ilk suçun icrasına devam edildiğini değil, yeni bir ihlalin başladığını gösterir. ${ }^{38} \mathrm{Bu}$ açıdan mütemadi suçta hareketlerin birleşmesine rağmen, tek ihlal olduğundan ortada tek suç vardır. ${ }^{39}$

32 Gülşen, s. 11.

33 Ekici Şahin, "Huzur ve Sükûnunu”, s. 40.

34 Parlar - Hatipoğlu, s. 1935; Yaşar - Gökcan - Artuç, s. 4069; Yenerer Çakmut, s. 72; Gülşen, s. 14. 'TCK'nın 123. maddesinde düzenlenen kişilerin huzur ve sükûnunu bozma suçunun temadi eden suç olduğu gözetilmeden, zincirleme suç hükümleri yerine, suça sürüklenen çocuğun eylemlerinin iki ayr suç olduğu kabul edilerek, fazla ceza tayin edilmesi ..." (Yargitay 4. CD. E. 2013/2444, K. 2013/18762, 13.06.2013) Aktaran: Yaşar - Gökcan - Artuç, s. 4076.

35 Kocasakal, s. 135; Ekici Şahin, "Huzur ve Sükûnunu”, s. 35.

36 Türkan Yalçın Sancar, Müteselsil Suç, B. 1, Ankara 1995, s. 30.

37 Yalçın Sancar, s. 31.

38 Ekici Şahin, “Huzur ve Sükûnunu”, s. 36.

39 Yalçın Sancar, s. 32. 
Kanaatimizce bu özellikleri itibariyle kişilerin huzur ve sükûnunu bozma suçuna vücut veren hareketler, özelliğine göre ani biçimde gerçekleştirilebileceği gibi kesintisiz biçimde de gerçekleştirilebilir. Tamamlanması için seçimlik hareketlerde ısrarın gerçekleşmesinin arandığı bu suçta, birden çok kere telefon etmek, elektronik mail göndermek, kapının önüne çöp koymak gibi davranışlar nitelikleri itibariyle mütemadi bir şekilde gerçekleştirilemez ve bu davranışların fail tarafindan birden çok kere gerçekleştirilmesi gerekir. Ancak müzik dinleyerek gürültü yapmak şeklindeki davranış, niteliği gereği belli bir zaman dilimi içinde devam etmelidir. Ancak bu hareketlerde kesinti gerçekleşse dahi ısrarın oluşabilmesi için, araya uzun bir zaman aralığı girmeksizin bu davranışların tekrarlanması gerekir. Öğretide, seçimlik hareketlerde aranan ısrarın mütemadiliği değil, itiyadı ifade ettiği ve seçimlik hareketin türüne göre temadinin tartışılabileceğini savunan görüşe ${ }^{40}$ katıllyoruz.

\section{Telefon Etmek}

Telefon etmek, birini telefonla aramak ve bir şey söylemek olarak tanımlanmaktadır. ${ }^{41}$ Bir kimsenin diğer bir kişiyi telefonla araması sabit hattan, cep telefonu veya araç telefonundan veya internet üzerinden ücretli ya da ücretsiz biçimde olabilir. ${ }^{42}$ Telefon etme seçimlik hareketi açısından belirleyici olan, failin kullandığı araç değil; mağdurla sabit, mobil veya araç telefonlarından biri aracılığıyla iletişim kurulmaya çalışılmasıdır. Failin kullandığ aracın mutlaka sesli veya hem sesli hem de görüntülü iletişim kurulmasını sağlayan ve teknik anlamda telefon olarak nitelendirilebilen bir araç olması gerekir.

Telefonla arandığında mutlaka karşı tarafla konuşmak gerekli değildir. Sadece çağrı yapmak, ${ }^{43}$ açıldıktan sonra telefonu kapatmak, ${ }^{44}$ telefonda karşı

40 Kocasakal, s. 136-137.

41 Bkz. http://www.tdk.gov.tr/ (04.04.2019)

42 Yenerer Çakmut, s. 54.

43 "Şikâyetçinin aşamalardaki iddiaları ve bu iddiaları doğrulayan Turkcell HTS raporuna göre; sanı̆̆ın abonesi olduğu cep telefonundan şikâyetçiye ait cep telefonunu birçok kez arayarak çaldırıp kapatmak suretiyle üzerine atılı kişilerin huzur ve sükûnu bozma suçunu işlediği sabit olduğu halde, dosyada mevcut delillere neden itibar edilmediği de açıklanmadan yazılı şekilde beraatine karar verilmesi ..." (Yargitay 2. CD. E. 
tarafa başka bir ses veya müzik dinletmek suçun oluşmasına vücut verebilecektir. Konuşmanın suç içeriği taşımasına da gerek yoktur. ${ }^{45}$

Mağdura mesaj gönderilmesi, telefon etmek seçimlik hareketi içinde nitelendirilemez. ${ }^{46}$ Ancak mesajın içeriğinde hakaret, tehdit veya cinsel taciz niteliğinde bir ifade yoksa ${ }^{47}$ ve surf kişinin huzur ve sükûnunu bozmak amacıyla; ${ }^{48}$ örneğin, boş mesaj veya failin kendi fotoğrafını göndermesi söz konusuysa, diğer seçimlik hareket olan "hukuka aykırı başka bir davranışta bulunulması" söz konusu olabilecektir. ${ }^{49}$ Doğrudan belirli bir kişiye gönderilmeyen, sosyal ağ paylaşımı çerçevesinde genele hitap eden Twitter

\footnotetext{
2008/33430, K. 2009/39858, 26.10.2009) Erişim:
http://www.kazanci.com/kho2/ibb/files/2cd-2008-33430.htm (04.04.2019)

44 "Müştekinin ev telefonunu birçok kez arayıp bir şey söylemeden kapatmak suretiyle rahatsı ettiği PTT tespit tutanăğ, müşteki ve eșinin anlatımları ile kanıtlanan sanığın eyleminin TCK'nın 547. maddesine uyan itidal ve muvazene dişı harekette bulunmak suçunu oluşturduğunun gözetilmemesi ...” (Yargitay 5. CD. E. 2003/450, K. 2003/1533, 27.03.2003) Erişim: http://www.kazanci.com/kho2/ibb/files/5cd-2003-450.htm (04.04.2019)

45 Yenerer Çakmut, s. 55.

46 Aksi yöndeki görüş için bkz. Kocasakal, s. 119.

47 "Aralarında hukuki uyuşmazlık bulunan ve üyesi bulunduğu Aksin Konut Yapı Kooperatifi'nin avukatı olarak görev yapan katılan cep telefonuyla ısrarla arayarak 15.09.2005 tarihinde 'Dosyanı yaptırdım, Allah bana yaptıklarının bin katını size versin.' 16.09.2005 günü saat 21.06, 21.15, 21.29, 21.42 ve 22.06'da strastyla 'Fakirlere vereceğimiz evleri bile verdirmedin, bunun hesabını nasıl vereceksin merak ediyorum.', 'Davaları kaybetsen bile evlerimi vereceğim dediğini unuttun, kazandığımı vermedin, seni de Allah'a havale ediyorum.', 'R.Ç. öldü, S.A.Ö. battı, sen şeker hastası oldun. T. karısını bıraktı. Ders almadınız.', 'Allah'a binlerce şükür alacaklıyım, A.Y. paramı inkâr etti, yine de batmadım, çok şükür borçlarımı ödeyecek durumdayım.' ve 'Binaya astığım yazıdan sonra çocuklarına nasıl dürüst ol, yalan söyleme diyecekler, merak ediyorum.' mesajların yazan sanığın eyleminin TCY'nin 123. maddesinde düzenlenen 'kişilerin huzur ve sükûnunu bozma' suçunu oluşturup oluşturmadı̆̆ tartışılmadan yazılı şekilde yasal olmayan gerekçelerle beraat karart verilmesi ..." (Yargitay 4 CD. 8109-3670, 09.03.2010) Aktaran: Parlar - Hatipoğlu, s. 1936.

48 "Sanı̆̆ın, yaşamın olağan akışına göre, bir konudaki meramını bir veya iki kez mesaj göndermekle belirteceği yerde, aynı anlamdaki mesajları gereksiz ve rahatsı edici biçimde, 3,5 saat içinde 4 kez katılana göndermesi biçimindeki eyleminin TCK 123. maddenin gerekçesinde belirtildiği üzere, 'ruhsal sükûn içinde yaşama hakkını' ihlal ettiği gözetilmeden, yasal olmayan gerekçeyle beraat kararı verilmesi ..." (Yargitay 4. CD. E. 2012/17641, K. $\quad$ K. 2013/1355, 24.01.2013) Erişim: http://www.kazanci.com/kho2/ibb/files/4cd-2012-17641.htm (04.04.2019)

49 Ekici Şahin, "Huzur ve Sük̂̂nunu”, s. 30. Boș mesaj atmak veya başka bir suçu oluşturmayacak şekilde mesaj veya resim atmanın telefon etme seçimlik hareketine dahil olduğu görüşü için bkz. Yaşar - Gökcan - Artuç, s. 4066.
} 
ve Facebook gibi iletişim uygulamalarının telefon yolu ile kullanılması telefon etme seçimlik hareketi kapsamında değildir. ${ }^{50}$

Telefonla arayanların kimler olduğu, mağdurun talebi ve telefonunun takibe alınması ile GSM operatörlerine müracaat üzerine sorularak öğrenilebilir. Ayrıca mağdurun başvurusu ve talebi ile telefon tespite alınarak da arayanların kim olduğuna ulaşmak mümkündür. ${ }^{51}$ Failin telefon kayıtlarının incelenmesinin, 5271 sayılı CMK m. 135/8 kapsamındaki katalog suçlar arasında kișilerin huzur ve sükûnunu bozma suçunun bulunmaması nedeniyle mümkün olmadığ ${ }_{1}$ ifade edilebilse de, ${ }^{52}$ CMK'nın 135/6. maddesinde düzenlenen telekomünikasyon yoluyla iletişimin tespiti tedbirinin katalog suçlarla sınırlı olmadığı, iletişimin tespiti tedbirinde iletişimin içeriğine müdahale etmeden iletişim araçlarının diğer iletişim araçlarıyla kurduğu iletişime ilişkin arama, aranma, yer bilgisi ve kimlik bilgilerinin tespit edilmesi ile yetinildiği, bu açıdan kişilerin huzur ve sükûnunu bozma suçunun oluşup oluşmadığının saptanmasında telekomünikasyon yoluyla yapılan iletişimin tespiti tedbirine

50 Kocasakal, s. 120.

51 Ancak Yargıtay uygulamasında, şüpheli ve sanık haricindeki kimselerin telefon kayıtlarının tespiti CMK m. 135'teki iletişimin tespiti, dinlenmesi ve kayda alınması yoluyla değil; CMK m. 160 ve 161 'de Cumhuriyet savcısına tanınan genel yetkiler çerçevesinde gerçekleştirilebilir. "İncelenen somut olayda, yakınanın 05.12.2005 ve 19.12.2005 tarihli dilekçelerde, kendisine karşı gerçekleştirilen telefonla tehdit ve hakaret suçlarının faillerinin belirlenebilmesi için ev ve cep telefonuyla belirttiği tarihlerde yaptı̆̆ görüssme kayıtlarının incelenmesini ve telefonun dinlenmesini istediği anlaşllmaktadır. Cumhuriyet Savcısinca ilgili telekom kurumuna gönderilen tespit yapılmasına ilişkin isteğin yerine getirilmediği, bunun üzerine Cumhuriyet Savcısının CMK'nın 135. maddesi uyarınca bir karar verilmesi için sulh ceza mahkemesine başvurduğu ancak yetkili hakimin soruşturulan suçun anılan yasa maddesinin 6-a fikrasında saylanlar arasında bulunmadığ gerekçesiyle isteğin reddine karar verdiği görülmektedir. Sulh ceza hakiminin verdiği kararın gerekçesi doğru olmamakla birlikte ulaşılan sonuç isabetlidir. Gerçekten de iletissimin tespiti tedbiri, CMK'nın 135/6 maddesindeki sinırlamaya bağl olmaksızın tüm suçlar açısından uygulanabilir. Ancak bu tedbire sadece şüpheli veya sanık için başvurulabilir. Yakınanin veya suçtan zarar görenin iletişimin tespitini, kimliği belirtilen yöntem sonucu belirlenebilecek șüpheli veya sanık için aleyhe kanıt olușturacak sonuca ulaşılsa bile 135. madde kapsamında değil, Cumhuriyet Savcısının 160 ve 161. maddelerde yer alan genel soruşturma ve kantt toplama yetkisi çerçevesinde değerlendirmek isabetli olacaktır. Ittirazı inceleyen merciin verdiği ret kararı da sonuç itibariyle doğru olduğundan hukuka uygundur ...” (Yargitay 4. CD. 4669-17007, 29.11.2006) Aktaran: Osman Yaşar, Yeni İçtihatlarla Uygulamalı ve Yorumlu Ceza Muhakemesi Kanunu, C. 2, B. 5, Ankara 2011, s. 1410.

52 Şen, s. 521. 
başvurulabileceği göz önünde bulundurulmalıdır. Yarg1 uygulamasında da, telefonla yapılan görüşmelere ilişkin detayların ve telefonla yapılan bağlantıların kimlerle ne zaman gerçekleştirildiğinin belirlenmesi anlamındaki tespitin katalog suçlarla sınırlı olmadığı ve dolayısıyla tespite ilişkin hükmün 8. fikra kapsamı dışında kalan suçlarda da uygulanabileceğine ${ }^{53}$ karar verildiği görülmektedir. ${ }^{54}$

\section{Gürültü Yapmak}

Suçu oluşturan diğer seçimlik hareket, 1 srarla gürültü yapılmasıdır. ${ }^{55}$ Akustik kirlilik olarak da adlandırılan gürültü, rahatsız edici ses veya alıcı tarafindan tahammül edilemeyen ve istenmeyen ses olarak, başka bir ifadeyle de istenmeyen seslerin oluşturduğu akustik bir olgu olarak tanımlanabilir. ${ }^{56}$

Gürültü yapılması, normal yaşam koşullanı içindeki ses yoğunluğunun üstünde, insan sağlı̆̆ını olumsuz yönde etkileyen ve onu rahatsız eden nitelikteki seslerin çıkartılmasıdır. Gürültü kavramı içine ritmik olanların yanında ritmik olmayan sesler de girer. Nitekim failin, kiracısını çıkartmak

53 “Kız kaçırma olayından dolayı Eyüp Cumhuriyet Başsavcılığı'nın 2005/13433 sayılı soruşturması sırasında şüphelinin kullandığ cep telefonu ile ilgili iletişimin tespiti talebi üzerine, soruşturma konusu suçun 5271 sayılı Ceza Muhakemesi Kanunu'nun 135/6 maddesinde sayllan suçlardan olmadiğından bahisle reddine dair Eyüp Sulh Ceza Mahkemesi'nin ... kararına vaki itirazın keza reddine ilişkin Eyüp 3. Asliye Ceza Mahkemesi'nin ... kararın ... kanun yararına bozmaya atfen ... gereği düşünüldü ... CMK'nin 135. maddesinin 6. fikrasinda bu madde kapsaminda 'dinleme, kayda alma ve sinyal bilgilerinin değerlendirilmesine' iliş̧kin hükümlerin fikrada sayılan katalog suçlarla ilgili olarak uygulanabileceği öngörülmüştür. Soruşturma evresinde şüphelinin kullandiğı telefonuyla yaptı̆̆ görüşmelere ilişkin detay bilgilerinin, yani telefonla yapılan bağlantıların kimlerle ve ne zaman yapıldı̆̆ının belirlenmesi anlamına gelen 'tespit' yukarıda belirtilen CMK'nın 135. maddesinin 6. fikrası kapsamı dışında bırakılmıştır. Bu nedenle hangi suça ilişkin olursa olsun, şüpheliye ait telefondan kimlerle ne zaman görüşüldüğüne dair 'tespit' CMK'nın 135/1 maddesi uyarınca hakim veya gecikmesinde sakınca bulunan hallerde cumhuriyet savcısının kararlyla mümkün olacaktır ..." (Yargitay 5. CD. 14969/20489, 03.10.2005) Aktaran: Yaşar, s. 1412.

54 Yenerer Çakmut, s. 57. Aynı yönde görüş için bkz. Yaşar, s. 1359; Gülşen, s. 9, dn. 16.

55 Gürültü yapma hareketi, telefon etme hareketinden farklı yapısal özellikler taşıdığından ısrar kapsamında en az iki defa tekrarını aramanın gerekli olmadığı, bu açıdan tek sefer olmakla birlikte uzun sayılacak gürültünün maddi unsura vücut verebileceği ifade edilmiştir. Bkz. Kocasakal, s. 123. Kanaatimizce, 1srar unsuru bütün seçimlik hareketler bakımından ortak bir unsur olarak arandığından, gürültü hareketinin de birden çok defa gerçekleştirilmesi aranmalıdır.

56 Parlar - Hatipoğlu, s. 1934. 
için huzur ve sükûnunu bozmak amacıyla kalorifer borularına 1srarla vurması, sürekli yüksek sesle müzik dinlenmesi, davul çalınması, fazla ses çıkaran sifonun açık bırakılması, evde devamlı parti yapılması, araba kornasına devamlı basılması $1,{ }^{57}$ evde sürekli tamir yaptırılması, çığırtkanlık yapılması ${ }^{58}$ sivri topuklu terlik giyilmesi, ${ }^{59}$ matkap kullanılması bu durumlara örnek gösterilebilir. ${ }^{60}$

Gürültü yapılırken, mekanik veya elektronik her türlü araç gereçten yararlanılabilir. Bizzat yüksek sesle şark1 söylenerek gürültü yapılabileceği gibi kuş, köpek gibi hayvanlar araç olarak kullanılabilir. ${ }^{61}$ Gürültü yapılan yerin mutlaka ev olmasına da gerek yoktur. İş yerinde, sokakta, bahçede, hatta piknik yapılan yerde dahi kişilerin huzur ve sükûnunu bozmak amacıyla gürültü yapılması bu kapsamdadır. ${ }^{62}$

\section{Hukuka Aykırı Başka Bir Davranışta Bulunmak}

Kişilerin huzur ve sükûnunu bozma suçu için öngörülen son seçimlik hareket ise, hukuka aykırı başka bir davranışta bulunulmasıdır. Bu hareket, çok farklı biçimlerde ortaya çıkabilecek niteliktedir.

Yarg1 kararları incelendiğinde; mağdurun sokakta yaya olarak veya araçla takip edilmesi, ${ }^{63}$ araçla selektör yapılması, ${ }^{64}$ mağdurun penceresine

57 "Oluş ve kabule göre, sevk ve idaresindeki otomobiliyle gece vakti, müşstekilerin evinin önünde durarak far yakıp söndüren ve korna çalmak suretiyle de müsstekilerin huzur ve rahatlarını ihlal eden sanığın eylemi sabit olup TCK'nın 547. maddesinde yazılı suçu oluşturduğundan ... yazılı şekilde beraat kararı verilmesi ...” (Yargıtay 5. CD. E. 1991/3210, $\quad$ K. $1992 / 4292, \quad 10.10 .1991) \quad$ Erişim: http://www.kazanci.com/kho2/ibb/files/5cd-1991-3210.htm (04.04.2019)

58 "Sanıkların Ankara Şehirlerarası Otobüs Terminali'nde, mensubu olduklarl otobüs firmasına ait biletleri satmak amacıyla çığırtkanlık yapmak şeklinde tezahür eden eyleminde atılı suçun yasal unsurlarının oluşmadı̆̆l, koşulları saptandiğında TCK'nın 547. maddesinin nazara alınabileceği gözetilmeden yazılı şekilde karar verilmesi ..." (Yargitay 2. CD. E. 2002/7582, K. 2002/5853, 05.04.2002) Erişim: http://www.kazanci.com/kho2/ibb/files/2cd-2002-7582.htm (04.04.2019)

59 Hafızoğulları - Özen, Kişilere Karşı, s. 227.

60 Yenerer Çakmut, s. 58.

61 Gülşen, s. 9.

62 Ekici Şahin, "Huzur ve Sükûnunu”, s. 30.

63 "Oluşa ve kabule göre, sanığın kullanmakta olduğu aracı ile yolda gördüğ̈̈ müştekiyi bir süre takip etmek suretiyle huzurunu bozduğu, edep ve nezahat hislerini rencide edecek bir davranışta bulunmadı̆̆ anlaşılmasına göre eylemine uyan TCK'nın 547. maddesi yerine yazılı madde ile hüküm tesisi ..." (Yargitay 5. CD. E. 1991/599, K. 1991/795, 19.02.1991) Erişim: http://www.kazanci.com/kho2/ibb/files/5cd-1991-599.htm (04.04.2019) 
1Ş1k veya ayna tutulması, uzaktan gözetlenmesi,${ }^{65}$ camına taş atılması $1,{ }^{66}$ ziline basılıp kaçılması, evine fare, yılan veya böcek bırakılması, sahip olunan hayvanların gübrelerinin bırakılmas $1,{ }^{67}$ geceleri balkonda mangal yakıp dumanın mağdurun evine dolmasına neden olunması gibi davranışlar bu seçimlik harekete vücut verebilecektir. ${ }^{68}$

Bunların dışında, tuvaletten mağdurun gözetlenmesi, ${ }^{69}$ çakmak yakılması, önünde giden aracın şoförünü rahatsız etmek amacıyla sürekli

64 "Olay tarihinde, sanığın yönetimindeki araçla, şehir merkezinde, katılanın idaresindeki aracı bir süre takip etmesi, takip sırasında katılanın yönetimindeki aracın yanına geçip, katılan ve yanındaki arkadașına, kendi aracında bulunan arkadaşlarıly birlikte gülmeleri, katılan hızını azalttığında kendisinin de aracın hızını azaltması, katılana selektör yapıp yanına geçmesi, katılanın polis merkezinin bulunduğu tarafa dönmesi üzerine takibi bırakmast şeklinde gerçekleşen olayda, sanığın gerçekleşen eyleminin 5237 sayılı TCK'nın 123/1. maddesinde tanımlanan kişilerin huzur ve sükûnunu bozma suçunu oluşturduğu gözetilmeden, yazılı gerekçelerle sanığın trafik güvenliğini tehlikeye sokma suçundan mahkûmiyetine karar verilmesi ..." (Yargitay 12. CD. E. 2011/5602, K. 2011/3661, 25.10.2011) Erişim: http://www.kazanci.com/kho2/ibb/files/12cd-2011-5602.htm (04.04.2019)

65 "Oluşa ve tanık Hatice Dikbaș'in anlatımından, sanı̆̆ın katılanın avlu duvarı üzerine çıkıp, eve bakmaktan ibaret eyleminin TCK'nın 547. maddesinde öngörülen suçu oluşturacă̆ı düşünülmeden, anılan yasanın 193/2. maddesiyle hüküm kurulması ..." (Yargitay 4. CD. E. 1993/8133, K. 1993/8769, 14.12.1993) Erişim: http://www.kazanci.com/kho2/ibb/files/4cd-1993-8133.htm (04.04.2019)

66 “Sanık I.Y'nin yakınan F.Ş'nin camına taş atarak uyarmadan ibaret eyleminin TCK'nın 547. maddesine uyan suçu oluşturup oluşturmadığ tartışılmadan hüküm kurulması ..." (Yargitay 4. CD. E. 1997/3575, K. 1997/4929, 09.06.1997) Erişim: http://www.kazanci.com/kho2/ibb/files/4cd-1997-3575.htm (04.04.2019)

67 "Mahkemece hükme esas alınan 24.08.2005 tarihli tutanakta bilgisine başvurulan ve her iki tarafin da komşusu olduğu anlaşılan Mehmet Sancaktar'ın savunmayı doğrular tarzdaki anlatımı ve olay yerindeki maddi bulgular karşısında Mehmet Sancaktar ve tutanak mümziileri tanık sıfatıyla dinlenmeden ve sanığın hayvanlarını bağlayıp gübrelerini bıraktığı iddia edilen yerler ile boru takmak suretiyle su döktüğ̈̈ yer belirlenip bu durumun müdahilin huzur ve sükûnunu bozucu nitelikte olup olmadiğı mahallinde yapılacak keșifle saptanmadan eksik inceleme ile yazılı șekilde hüküm tesisi ..." (Yargıtay 2. CD. 689-4663, 02.04.2007) Aktaran: Parlar - Hatipoğlu, s. 1937-1938.

68 Ekici Şahin, "Huzur ve Sükûnunu”, s. 31.

69 "Sanı̆̆ın izinsiz olarak girdiği ve yakınanın tuvalet penceresinden içeriye baktı̆̆ yerin mahalle camiine ait herkese açık avlu bulunduğu keșifle belirlenmiş bulunmasına göre, girilen bu yerin ne suretle konut eklentisi sayıldığ a açıklanmadan ve eylemin TCK'nın 547. maddesine uyup uymadiğ tartışllmadan, salt bilirkişi düşüncesine dayanılarak hüküm kurulması ..." (Yargitay 4. CD. E. 1992/3815, K. 1992/4614, 23.06.1992) Erişim: http://www.kazanci.com/kho2/ibb/files/4cd-1992-3815.htm (04.04.2019). "Sanığın, evinin avlusunda bulunan tuvalete giren mă̆dureyi tuvalet duvarındaki delikten hiçbir söz sarf etmeden gözetlemekten ibaret eyleminin TCK'nın 547. maddesine uyan itidal ve muvazene harici hareket niteliğinde kaldı̆̆ gözetilmeden yazılı şekilde sarkıntılık suçundan hüküm 
uzun farların yakılması ${ }^{70}$ halı çırpılması, mağdurun görüntülerinin kameraya alınması ${ }^{71}$ pencere camının tıklatılması,${ }^{72}$ kapı önünden geçen kimseye su dökülmesi, mağdurun adının sürekli söylenerek rahatsız edilmesi, ${ }^{73}$ evin penceresinden içeri bakılması,${ }^{74}$ yurtdışından gelen turistlere belli otellere yönlenmeleri için israrda bulunulması,${ }^{75}$ bahçeye komşuyu rahatsız edecek nitelikte çöpler dökülmesi, ${ }^{76}$ kapının dinlenmesi, lazer 1 şı tutulması, ${ }^{77}$

kurulması ..." (Yargitay 5. CD. E. 2001/4554, K. 2002/2049, 01.04.2002) Erişim: http://www.kazanci.com/kho2/ibb/files/5cd-2001-4554.htm (04.04.2019)

70 Özbek - Kanbur - Doğan - Bacaksız - Tepe, s. 444.

71 "Sanı̆̆ın israrlı şekilde ve değişik zaman dilimlerinde, kamera ile katılanın görüntülerini çekmesi şeklindeki eyleminin 5237 sayll TCK'nın 123. maddesinde tanımlanan suçu oluşturacă̆l, hukuki durumun buna göre değerlendirilmesi gerektiği gözetilmeyerek yazll ssekilde beraatine karar verilmesi ..." (Yargitay 12. CD. E. 2011/20055, K. 2012/5809, 01.03.2012) Erişim: http://www.kazanci.com/kho2/ibb/files/12cd-2011-20055.htm (04.04.2019)

72 "Yol üzerinde bulunan evin, pencere camını tıklatmaktan ibaret olan sanığın eyleminin TCK'nın 547. maddesine uygun, itidal ve muvazene dişı hareket suçunu oluşturduğu gözetilmeden ayrıca mesken masuniyetini ihlale teşebbüs suçundan da hükümlülüğüne karar verilmesi ...” (Yargitay 4. CD. E. 1982/345, K. 1982/794, 09.02.1982) Erişim: http://www.kazanci.com/kho2/ibb/files/4cd-1982-345.htm (04.04.2019)

73 "Sanı̆̆ın olay gecesi mağdurenin yatak odası penceresi yanına gelerek itip açması ve 'Filiz' diyerek ismen çağırmasından ibaret eyleminin, mağdurenin iffetine dokunacak bir söz sarf edilmemesi itibariyle TCK'nın 547. maddesine uygun suçu oluşturduğu gözetilmeden yazılı şekilde söz atmadan hüküm tesisi ..." (Yargitay 5. CD. E. 1992/4098, K. 1993/108, 21.01.1993) Erişim: http://www.kazanci.com/kho2/ibb/files/5cd-19924098.htm (04.04.2019)

74 “25.11.1990 tarihli olayda ise sanıklar Asım Şakar ve Ergün Güneş'in, müştekilerin evinin etrafinda dolaşıp pencereden içeriye bakmalarının TCK'nın 547. maddesine uyar nitelikte olup olmadı̆̆ tartışılmadan cezanın 80. madde ile artırılması ...” (Yargıtay 4. CD. E. 1991/6877, $\quad$ K. $\quad 1991 / 7699, \quad 10.12 .1991) \quad$ Erişim: http://www.kazanci.com/kho2/ibb/files/4cd-1991-6877.htm (04.04.2019)

75 "Tüm dosya kapsamına göre, sanıkların Atatürk Havalimanı dış hatlar terminalinde yurtdışından gelen yolcuları, satış temsilcisi olarak çalıştıkları şirketlere ait otellere yönlendirmek şeklindeki eylemlerinin TCK'nın 547. maddesi kapsamında olduğu ..." (Yargitay CGK. E. 2006/7-156, K. 2006/151, 06.06.2006) Erişim: http://www.kazanci.com/kho2/ibb/files/cgk-2006-7-156.htm (04.04.2019)

76 Gülşen, s. 10.

77 "Mahkemece sanığın, mağdureye sakız vermek isteyerek diyalog kurmaya çalıştığı, mağdurenin kendisi ile konuşmaması üzerine evlerinin mutfak camına değişik zamanlarda ısrarla taş, kar topu attı̆̆ ve lazer ışığı tuttuğu oluşa uygun şekilde kabul edildiği halde, sanığın eylemlerinin 5237 sayll TCK'nın 123. maddesinde düzenlenen kişilerin huzur ve sükununu bozma suçunu oluşturduğu gözetilmeksizin ... karar verilmesi ...” (Yargitay 14. CD. E. 2011/19260, K. 2012/5268, 09.05.2012) Aktaran: Yaşar - Gökcan - Artuç, s. 4091. 
mağdurun arzusu hilafına onun adına bağışlamada bulunulmass $1{ }^{78}$ mektup, telgraf, faks, internet vb. iletişim araçlarıyla kişilerin rahatsız edilmesi ${ }^{79}$ gibi hareketler söz konusu seçimlik hareketin kapsamındadır.

Hukuki konu kısmında açıklandığı üzere, her ne kadar bu suçla kişinin iç barış1, huzur ve sükûnu korunmak istense de; söz konusu seçimlik hareketle ceza müeyyidesine başvurulması hukuk güvenliği ve kanunilik ilkesi açısından eleştiri konusudur. Zira kanun koyucu ceza normlarını oluştururken hangi fiillerin suç olduğunu ve cezasının ne olacağını açıkça belirlemelidir. Yasaklanan davranışlar yeterince açık bir biçimde belirtilmediğinde, normun muhatapları normun içeriğini bilme olanağına sahip olamayacağından; davranışlarını hukuka uygunluk sınırları içinde kalarak yönlendiremezler. Bu açıdan bakıldığında, TCK m. 123'te yer alan "hukuka aykırı başka bir davranışta bulunulması" seçimlik hareketi, sınırları belli olmayan, cezalandırılan davranışların alanını belirsiz biçimde genişleten ve kanunilik ilkesi açısından son derece sakıncalı bir düzenlemedir. ${ }^{80} \mathrm{Bu}$ durum, uygulamada komşuluk hukukuna aykırılık teşkil eden ve özel hukuk yöntemleriyle çözümlenebilecek uyuşmazlıkların dahi ceza hukuku alanına dahil edilmesi riskini ortaya çıkaracaktır. ${ }^{81}$ Kişilerin huzur ve sükûnunu bozma suçundaki söz konusu seçimlik hareketin Anayasa'nın 2 ve 38. maddelerine aykırı olduğu iddiasıyla iptalinin istendiği davada, Anayasa Mahkemesi'nin hükmün suçta ve cezada kanunilik ilkesine aykırılık teşkil etmediği, normun koruduğu hukuki değer dikkate alındığında kanun koyucunun bu hareketleri tek tek saymasının mümkün olmadığı ve fiilin farklı hareketlerle işlenebilir olmasının belirlilik ilkesini ihlal etmediği

78 "Sanı̆̆ın aynı işyerinde çalıştı̆̆ ve ilgi duyduğu katılana, aralarında bir yakınlık varmış izlenimi yaratan, günlük yaşamına ilişkin detaylar içeren pek çok elektronik postayı, katılanın ve işyeri yönetiminin uyarısına rağmen, ısrarla ilettiği, yine katılanın rızası dışında onun adına vakıflara bağışta bulunup dekontlarını ona gönderdiğinin anlaşılması karşısında, saniğın eylemlerinin kişinin huzur ve sükûnunu bozma suçunu oluşturduğu gözetilmeden, yasal ve yerinde olmayan gerekçe ile beraat kararı verilmesi ..." (Yargıtay 4. CD. E. 2012/30048, K. 2013/853, 21.01.2013) Aktaran: Yaşar - Gökcan - Artuç, s. 4068 , dn. 2465.

79 Hafızoğulları - Özen, Kişilere Karşı, s. 227.

80 Suçta ve cezada kanunilik ilkesinin alt unsurlarından olan suçta ve cezada belirlilik için bkz. Nur Centel - Hamide Zafer - Özlem Çakmut, Türk Ceza Hukukuna Giriş, B. 10, İstanbul 2017, s. 56.

81 Ekici Şahin, "Huzur ve Sükûnunu”, s. 31. Benzer yönde eleştiriler için bkz. Kocasakal, s. 123-124; Şen, s. 520; Fahri Gökçen Taner, Türk Ceza Hukukunda Cinsel Özgürlüğe Karşı Suçlar, B. 1, Ankara 2013, s. 373. 
yönündeki gerekçesiyle iptal istemini reddetmesi kanaatimizce isabetli olmamıştır. $^{82}$

\section{B. HUKUKA AYKIRILIK}

Fiil ile hukuk düzeni arasında bir çelişme söz konusu olduğunda hukuka aykırı fiilden bahsedilir. ${ }^{83}$ Suçun unsurları konusunda benimsenen görüşlere göre değişmekle birlikte, ${ }^{84}$ hukuka aykırılık, tipik fiilde hukuka uygunluk

82 "8. İtiraz konusu kuralla, sirf huzur ve sükûnunu bozmak maksadiyla bir kimseye ısrarla hukuka aykırı bir davranışta bulunulması, "kișilerin huzur ve sükûnunu bozma suçu" şeklinde düzenlenerek yaptırıma bağlanmaktadır. Kuralın yer aldiğı maddenin gerekçesinde de belirtildiği üzere maddeyle, kişilerin huzur ve sükûnlarının bozulması hususunda gösterilen çabalar cezalandırllmaktadır. Bu bağlamda kuralla korunan hukuki değer, insanın huzurlu, sakin ve sağllklı bir ortamda yaşama hakkıdır. 9. Kanun koyucunun itiraz konusu kuralla, sırf huzur ve sükûnunu bozmak maksadiyla bir kimseye ısrarla maddede belirtilen eylemlerin yanı sıra aynı maksatla hukuka aykırı başka eylemlerde bulunulması hallerinde de ceza yaptırımı öngörmek suretiyle kișilerin huzurlu bir ortamda, rahatsız edilmeden, huzur ve sükûn içinde yaşamlarını ve faaliyetlerini sürdürmesini sağlamayı amaçladı̆̆ı anlaşılmaktadır. Maddede huzur ve sükûnu bozmak maksadiyla bir kimseye ısrarla telefon edilmesi, gürültü yapılması şeklinde davranışlar sayıldıktan sonra aynı maksatla yapılan hukuka aykırı diğer davranışların da bu suçu oluşturacağının kabul edilmesinin, hukuki belirsizliğe yol açacağı söylenemez. Zira kanun metni bir bütün olarak değerlendirildiğinde ve maddeyle korunmak istenen hukuki yarar da göz önüne alındığında, itiraz konusu kuralın huzur ve sükûnu bozucu nitelik taşıyan hukuk düzenine aykırı davranışları ifade ettiği anlaşılmaktadır. Suç olarak düzenlenen fiilin, farkl h hareket biçimleriyle işlenebilir olması, belirsiz olduğu anlamina gelmez. Dolayısıla itiraz konusu kuralın "belirlilik" ilkesine aykırı bir yönü bulunmamaktadır. 10. Öte yandan, bir kimsenin sırf huzur ve sükûnunu bozmak maksadiyla yapılacak "hukuka aykırı davranışlar" çok farklı şekillerde ortaya çıkabileceğinden bu kavrama giren tüm davranışların kanun koyucu tarafindan önceden belirlenmesi ve tek tek saylmasl zorunluluğundan söz edilemez. Kanun'un, hangi eylemin suç teșkil ettiğinin ve bu eyleme bağlanan yaptırımın ne olduğunun, belli bir açıklık ve kesinlikte öngörülebilmesine imkân verecek şekilde kaleme alınmış olması, kanunilik ilkesinin sağlanması bakımından yeterlidir. Yukarıda açılklandiğg üzere, itiraz konusu kuralla, Kanun'da sırf huzur ve sükûnunu bozmak maksadıyla hukuka aykırı bir davranışta bulunulması hali suç olarak düzenlenerek buna ilişsin yaptırım da belirlenmiş olduğundan, kuralın suç ve cezaların kanuniliği ilkesine aykırı bir yönü de bulunmamaktadır. 11. Açıklanan nedenlerle kural, Anayasa'nın 2. ve 38. maddelerine aykırı değildir. İptal isteminin reddi gerekir." (Anayasa Mahkemesi, E. 2016/44, K. 2016/153, 07.09.2016). Bkz. R.G., 11.10.2016, S. 29854.

83 Tuğrul Katoğlu, Ceza Hukukunda Hukuka Aykırılık, B. 1, Ankara 2003, s. 19.

${ }^{84}$ Suçun unsurları ve ayrımı konusunda bkz. Katoğlu, s. 127 vd.; Toroslu, s. 106 vd.; Zeki Hafızoğulları - Muharrem Özen, Türk Ceza Hukuku Genel Hükümler, B. 8, Ankara 2015, s. 163 vd.; Timur Demirbaş, Ceza Hukuku Genel Hükümler, B. 6, Ankara 2009, s. 194 vd.; Centel - Zafer - Çakmut, s. 212 vd.; Mehmet Emin Artuk - Ahmet Gökcen Ahmet Caner Yenidünya, Ceza Hukuku Genel Hükümler, B. 9, Ankara 2015, s. 201 vd. 
nedenlerinin bulunmamasını ve bu sayede fiilin hukuk düzeni ile çatışma içinde olmasını ifade eder.

Kişilerin huzur ve sükûnunu bozma suçu açısından TCK m. 26/2'de düzenlenmiş olan ilgilinin rızası bir hukuka uygunluk nedenidir. Rıza, rıza gösterme ehliyet ve yetkisine sahip olan kişinin, üzerindeki tasarruf yetkisi hukuk düzeni tarafından kendisine bırakılmış bir hukuksal değerine karşı gerçekleştirilen ve söz konusu hukuksal değeri tehlikeye düşüren veya zarara uğratan bir fiili kabul etmesi, onaylamasıdır. ${ }^{85}$ Geçerli bir rıza için üzerinde tasarruf edilebilecek bir hukuksal değer olmalı, ilgilinin rıza gösterme ehliyeti bulunmalı, rıza özgür ve sağlıklı bir iradeye dayanmalı ve ilgili rızasını açıklamalıdır. ${ }^{86}$ Kişi; iç hürriyeti, ruhsal ve psikolojik açıdan rahatsız edilmeme, sulh ve sükûn içinde yaşama hakkı üzerinde serbestçe tasarrufta bulunabileceğinden, bu değere yönelik gerçekleştirilecek eylemlere karşı rıza gösterebilir. Somut olayda rızanın diğer şartları da varsa, TCK m. 123'te gösterilen davranışların icrasından önce veya en geç icra edildiği sırada gösterilmesi şartıyla, rıza bir hukuka uygunluk nedeni olacaktır. ${ }^{87}$

Kişilerin huzur ve sükûnunu bozma suçu açısından hakkın icrası da bir hukuka uygunluk nedeni olabilir. Bir meslek veya sanatın icrası kapsamında yapılan gürültü veya sair bir davranış, fiili hukuka uygun hale getirebilir. Örneğin, bakırcı ustasının bakır dövmesi, sokaklarda işlerini yapan seyyar satıcılardan simitçi veya eskicinin bağırması veya telefon arızalarını kontrol eden bir görevlinin arızanın tespiti için telefon etmesi hallerinde, gerçekleştirilen eylemler bir meslek ve sanatın icrası kapsamında hukuka

85 Meral Ekici Şahin, Ceza Hukukunda Rıza, B. 1, İstanbul 2012, s. 7.

86 Ekici Sahin, Rıza, s. 111 vd.

87 Ekici Şahin, "Huzur ve Sükûnunu”, s. 42. "Mağdurenin aşamalarda değişmeyen anlatımları, sanığın kaçamaklı ikrarı, HTS raporları ve tüm dosya kapsamına göre; sanı̆̆ın, mağdurenin cep telefonuna 'Aşkım beni zorlama otele gidecez mi sürpriz yapalım istiyorsan, birazdan gidelim', 'yemin ederim hayatında tatmadı̆̆ın zevki tadacaksin yeter ki evet de', 'aşkım ben de evliyim benden laf çıkmaz' biçimlerinde kırk adet mesaj atması şeklindeki eylemlerine karşılık mağdurenin de aynı zaman dilimleri içerisinde sanı̆̆a içeriği teknik olarak saptanamayan yirmibeş adet mesaj göndermesi karşısında, saniğın eylemini mağdurenin rızasıyla gerçekleștirilip gerçekleștirilmediğine iliş̧kin șüphe oluştuğundan ve rıza dişında mağdureye mesaj atılmış olduğuna ilişkin yeterli ve kesin delil elde edilemediğinden, beraat kararl verilmesi gerekirken TCK'nun 123. maddesi uyarınca mahkûmiyet kararı verilmesi" (Yargitay 4. CD. E. 2013/18706, K. 2014/10836, 03.04.2014) Aktaran: Kocasakal, s. 139, dn. 70. 
uygundur. ${ }^{88}$ Yine alacaklının alacağını istemek amacıyla borçluya ısrarla telefon etmesi, ${ }^{89}$ evi tahliye etmeyen kiracıya karşı, evin su sayacının sökülmesi için belediyeye başvuran kiralayanın eylemleri ${ }^{90}$ hakkın kötüye kullanılması kapsamında olmadığı müddetçe suç teşkil etmeyecektir. Yine Ramazan ayında davul çalınması ve asker uğurlama törenleri gibi faaliyetler de örf ve adetten kaynaklanan ve hukuka uygunluk sınırları içinde kalan hareketlerdir. ${ }^{91}$

\section{MANEVİ UNSUR}

Kusurluluk, suçu oluşturan maddi fiile neden olan iradenin ödeve aykırı davranışı olarak tanımlanmaktadır. ${ }^{92}$ Fail ile fiil arasındaki bu psikolojik bağ, kast veya taksir biçiminde ortaya çıkar. ${ }^{93}$

Kişilerin huzur ve sükûnunu bozma suçunun maddi unsurunu oluşturan 1srarla telefon edilmesi, gürültü yapılması veya hukuka aykırı başka bir davranışta bulunulması hareketlerinin, "sırf bir kimsenin huzur ve sükûnunu

88 Ekici Şahin, "Huzur ve Sükûnunu”, s. 42. Sayılan bu hallerde, hareketin belirli bir kişiye yönelmediği ve özel kastın bulunmadığı da göz önünde bulundurulmalıdır.

89 Hafızoğulları - Özen, Kişilere Karşı, s. 228. Yargıtay'ın bu konuda aksi yönde kararları mevcuttur. "Sanı̆̆ın, borcunu ödemeyen yakınanı, alacağını tahsil etmek için hukuki yollara başvurmak yerine, iki ay boyunca ve bir gün içinde çok kısa aralıklarla defalarca ısrarla telefonla araması eyleminin, yakınanın huzurunu bozmak kastıyla yapıldığını gösterdiği ve yakınanın huzur ve sükûnunu bozduğu ve suçun ögeleri oluştuğu gözetilmeden, alacă̆ını tahsil etmek amacıyla eylemi gerçekleştirdiği, ... sirf huzur ve sükunu bozmak özel kastının bulunmadığı biçimindeki ... gerekçe ile beraat kararı verilmesi ..." (Yargitay 2. CD. E. 2010/18208, K. 2012/8536, 04.04.2011) Aktaran: Yaşar - Gökcan - Artuç, s. 4086.

90 "Sanı̆̆a ait evde kiracı olarak oturan katılanın, sanığın evi boşaltması yönündeki istemine rağmen evde kalmaya devam etmesi üzerine, sanı̆̆ın İzmir Su ve Kanalizasyon İdaresi Genel Müdürlüğ̈̈'ne başvurup aboneliğinin bulunduğu su sayactnın sökülmesini talep ettiği, belediyeden yetkililerin gelip su sayacını söktükleri olayda, 5237 sayıl TCK'nın 123. maddesinde 'sırf huzur ve sükûnunu bozmak maksadiyla bir kimseye ısrarla; telefon edilmesi, gürültü yapılması ya da aynı maksatla hukuka aykırı başka bir davranışta bulunulması' biçiminde tanımlanan kişilerin huzur ve sükûnunu bozmak suçunun yasal unsurlarının oluşmadığ için ısrarla hukuka aykırı herhangi bir davranışının tespit edilemediği gözetilmeden, yetersiz gerekçelerle yazılı şekilde hüküm kurulması ...” (Yargıtay 2. CD. E. 2010/38449, K. 2012/42694, 03.10.2012) Erişim: http://www.kazanci.com/kho2/ibb/files/2cd-201038449.htm (04.04.2019)

91 Kocasakal, s. 140.

92 Toroslu, s. 176.

93 Devrim Güngör, Ceza Hukukunda Fiil Üzerinde Hata, B. 1, Ankara 2007, s. 35. 
bozmak saikiyle" gerçekleştirilmesi gereklidir. Dolayısıyla suç ancak özel kastla işlenebilir; ${ }^{94}$ genel kast suçun oluşması için yeterli değildir. ${ }^{95}$ Fail, mağdurun huzur ve sükûnunu bozmayı ve onu rahatsı etmeyi istemeli ve amaçlamalıdır. ${ }^{96}$ Sırf protesto amacıyla gerçekleştirilen eylemler süreklilik taşısalar bile, TCK m. 123 'te yer alan huzur ve sükûnu bozma suçuna vücut vermez. ${ }^{97} \mathrm{Bu}$ nedenle protesto amaçlı ve süreklilik niteliği taşıyan eylemler ile ses çıkarılması bu suçu oluşturmaz. ${ }^{98}$ Aynı şekilde, cep telefonlarına gelen reklam amaçlı veya kamuoyu oluşturmak için gönderilmiş olan mesajlar da bu suça vücut vermez. ${ }^{99}$ Yargıtay kararlarında, hareketlerin belirli sayıda yapılmasının özel kastı ortaya koymak açısından yeterli olmadığ 1 , hareketlerin yapılmasının ardında bulunan nedene önem verildiği, bu noktada da meşru amaç ölçütüne başvurulduğu görülmektedir. ${ }^{100}$

94 "Katılanın üst katında oturan sanığın ev içinde gürültü yapma ve eşyaların tozunu balkondan aşağıya silkeleme gibi eylemlerinde 'sırf huzur ve sükûnu bozma' özel kastının ne şekilde oluştuğu açıklanıp tartışılmadan hüküm kurulması ...” (Yargitay 4. CD. E. 2012/29621, K. 2013/1276, 23.01.2013) Aktaran: Yaşar - Gökcan - Artuç, s. 4072, dn. 2481.

95 "Suça konu yerin, binanın otopark olarak kullanılan ortak kullanım alanı olduğu, katılanın zemin katta olup, ışık alan tek penceresinin bulunduğu, aynı yere otomobil park edildiğinde problem olmamasına rağmen minibüs park edilmesi halinde katılanın evinin ışık almasının engellendiği, sanığın ruhsatı üzerine olmayan ve arızalı minibüsü katılanın penceresinin önüne sürekli biçimde 2 yll gibi uzun süre ve hareket ettirmeksizin park ederek saniğı rahatsız ettiği, daha önceden husumetli olduğu katılanın minibüsün alınmasını istediğinde özellikle almayıp, minibüsü aynı yerde ısrarla tutması karşısında, sanığın katılanın huzur ve sükununu bozmak kastıyla hareket ettiğinin kabulü yerine ... beraat kararl verilmesi" (Yargitay 4. CD. E. 2012/17709, K. 2013/1357, 24.01.2013) Aktaran: Yaşar - Gökcan - Artuç, s. 4068, dn. 2465.

96 Yenerer Çakmut, s. 68; Ekici Şahin, "Huzur ve Sükûnunu”, s. 41; Parlar - Hatipoğlu, s. 1935; Hafızoğulları - Özen, Kişilere Karş1, s. 228. "Suça sürüklenen çocuğun olay günü katılan Mehmet Ali K. 'ın evinin önüne gelerek ıslık çalma ve etrafa tekme atarak gürültü yapma biçiminde kabul edilen eyleminde, suça sürüklenen çocuğa yükletilen kişilerin huzur ve sükûnunu bozma suçunun 'israrla ve rahatsı etme özel kastı ile davranma' ögelerinin ne suretle oluştuğu açıklanıp tartışılmadan, yetersiz gerekçe ile hüküm kurulması ..." (Yargitay 4. CD. E. 2013/1571, K. 2013/13045, 30.04.2013) Aktaran: Yaşar - Gökcan - Artuç, s. 4075. "Sanı̆̆ın değişik zamanlarda boşanma aşamasında olduğu eşine gönderdiğ mesajların sitem mahiyetinde olduğu ve TCK'nun 123. maddesinde öngörülen 'sırf rahatsız etme' maksadıyla gönderildiği kanısını uyandıran nitelik arzetmediği gözetilmeden mahkûmiyet kararı verilmesi" (Yargitay 4. CD. E. 2013/34431, K. 2014/15319, 06.05.2014) Aktaran: Kocasakal, s. 141, dn. 80.

97 Yenerer Çakmut, s. 69.

98 Özbek - Kanbur - Doğan - Bacaksız - Tepe, s. 445.

99 Gökcen, s. 35.

${ }^{100}$ Kocasakal, s. 142. "Sanığın, müşterek çocukları bulunan ve gayrı resmi birliktelik yaşadı̆̆ı şikâyetçiye, ayrıldıktan sonra 7 ay içinde 7 kez tekrar bir araya gelme teklifini 
Suçun taksirli haline Kanun'da yer verilmemiştir. Bir kimsenin huzur ve sükûnunu bozmak amaciyla değil de, başka amaçla telefon edilmesi, evde tadilat amacıyla için gürültü yapılması veya sokak satıcısının mallarını satabilmek amacıyla bağırması hallerinde huzur ve sükûnu bozma amacı bulunmamaktadır. ${ }^{101}$

Failin şahıs üzerinde hata yaparak, huzur ve sükûnunu bozmak istediği kişiden başka bir kişiye karşı eylemlerini gerçekleştirmesi TCK m. 123'ün oluşumu bakımından önemli değildir. ${ }^{102}$ Zira şahısta hata olarak adlandırılan durum, hata sonucu bir suç fiilinin istenenden başka birisine karşı işlenmiş olmasıdır. Pasif süjenin kimliği kural olarak suç fiilinin esaslı bir unsuru sayılmaz. Bu itibarla, mağdurun kim olduğu konusunda hataya düşülmesi kastın varlığını etkilemez. ${ }^{103}$ Örneğin, eski sevgilisinin huzur ve sükûnunu bozmak isteyen failin, sevgilisinin telefonunu kardeşine verdiğinden habersiz, defalarca telefon etmesi halinde de, şahısta hata vardır ve bu hata önemsizdir. ${ }^{104}$ Aynı şekilde, iç hat sistemi olan bir apartmanda, üst

içerir cep telefonu mesajları göndermekten ibaret eyleminde, söz konusu mesajların aralarındaki ilişsiye binaen meşru bir amaç için gönderilmesi nedeniyle kişilerin huzur ve sükununu bozma suçunun özel kast unsurunu oluşturmayacă̆ gözetilmeden, yasal olmayan gerekçe ile mahkumiyet kararı verilmesi" (Yargitay 4. CD. E. 2012/34372, K. 2014/1756, 28.01.2013) Aktaran: Kocasakal, s. 142, dn. 83.

${ }^{101}$ Bununla birlikte söz konusu fiiller, 5236 sayılı Kabahatler Kanunu'nun 37. maddesi uyarınca idari yaptırımla cezalandırılabilecektir. "Rahatsız etme" madde başlıklı hüküm, "Mal veya hizmet satmak için başkaların rahatsız eden kişi, elli Türk Lirası idari para cezası ile cezalandırılır" biçiminde düzenlenmiş ve seyyar satıcıların, bayi temsilcilerinin, otogarda yer alan otobüs işletmecilerinin vb. kişilerin bulundukları yerlerde yüksek sesle mal veya hizmetlerini satmak amacıyla bağırmalarını müeyyide altına almıştır. Bkz. Yenerer Çakmut, s. 93.

102 Ekici Şahin, "Huzur ve Sükûnunu”, s. 41.

103 Güngör, Hata, s. 75.

${ }^{104}$ Yargitay bir kararında, mağdurun kimliğini bu suçta esaslı unsur sayarak; failin, mağdurun kimliği konusunda düştüğü hatadan TCK m. 30/1 uyarınca yararlanması gerektiğine hükmetmiştir. "Sanığın, mağdure Emine'nin ev telefonunu birçok kez arayıp konuşmadan kapatması, devamında mă̆dure Emine'ye yönelik söylediğini zannederek, mağdure Rukiye'ye yönelik telefonda birçok kez 'seni seviyorum, güzelliğin bozulmasın, banyoya gidelim vb.' sözleri söyleyip mağdure Emine'nin kocası öbür mağdur Adem’i dövmekle birçok kez tehdit etmesi karşısında, mağdure Emine'ye ilişkin eylemleri nedeniyle TCK'nın 123/1, 105/1, 43 ve 106/1; mağdur Adem'e ilişkin yokluğunda tehdit eylemi nedeniyle 106/1, 43 maddeleri uyarınca cezalandırılması gerektiğinin gözetilmemesi, ... Mağdure Rukiye'ye yönelik eylemlerinin Emine'yi kastederek ve o olduğunu sanarak gerçekleştirmesi karşısında; TCK'nın 30/1 maddesinde öngörülen fiilin icrası sırasında suçun kanuni tanımındaki maddi unsurlardan olan mağdurdaki hata nedeniyle sanığın, Rukiye'ye yönelik işlediği iddia olunan suçlardan beraati yerine her mağdur için ayrı ayr 
komşusunun huzur ve sükûnunu bozmak isteyen failin, üst komşunun zannederek yan komşusunun iç hat telefonunu israrla araması halinde de, suç kastı ortadan kalkmamaktadır. ${ }^{105}$

\section{SUÇA ETKİ EDEN NEDENLER}

Kişilerin huzur ve sükûnunu bozma suçu açısından, kanunda özel bir ağırlatıcı ya da hafifletici neden düzenlenmemiştir. ${ }^{106}$ Genel hükümler arasında yer verilen ve tüm suçlar için geçerli olan genel hafifletici nedenler koşulları varsa bu suçta da geçerli olacaktır. Dolayısıyla haksız tahrik ve genel takdiri indirim nedenleri, koşulları bulunmak şartıyla bu suç bakımından da uygulanabilecektir. ${ }^{107}$

\section{SUÇUN ÖZEL GÖRÜNÜŞ BİÇIMLERİ}

\section{A. TEŞEBBÜS}

Her ne kadar neticesiz bir suç da olsa, kişilerin huzur ve sükûnunu bozma suçunda, suçu oluşturan hareketlerin parçalara bölünebilmesinden ötürü suça teşebbüsün mümkün olduğu ifade edilmektedir. ${ }^{108}$ Fail, bir başkasının huzur ve sükûnunu bozmak amaciyla ilk defa telefon ettiği veya ilk defa gürültü yaptığı veya başka bir hukuka aykırı davranışta bulunduğu anda suçun icra hareketlerine başlar. Suçun tamamlanması için ise, TCK m. 123 ’te sayılan seçimlik hareketlerden birinin veya birkaçının amaç birliği

TCK'nın 105/1, 43, 106/1, 123/1, 43 maddeleri gereğince mahkûmiyet hükümleri kurulması ..." (Yargitay 14. CD. E. 2011/6444, K. 2012/8973, 25.09.2012) Erişim: http://www.kazanci.com/kho2/ibb/files/14cd-2011-6444.htm (04.04.2019). TCK'nın 106. maddesinde düzenlenen tehdit suçundakinin aksine kișilerin huzur ve sükûnunu bozma suçunda, "yakınının” ibaresine TCK m. 123'te yer verilmediği, bu itibarla telefon etme veya gürültünün mağdurun şahsına yöneltilmeyip, mağdurun yakınlarına karşı gerçekleştirilmesi durumunda, söz konusu davranışların mağdura yöneltilmiş̧ sayılamayacağ1 görüşü için bkz. Kocasakal, s. 118-119. Kanaatimizce de, suçta ve cezada kanunilik ilkesi gereğince, bu halde davranışların mağdura yönelmiş olduğundan bahsedilemez.

105 Ekici Şahin, "Huzur ve Sükûnunu”, s. 41.

${ }^{106}$ Failin kamu görevlisi olması, suçun belirli bir meslek veya sanatın icrası kapsamında işlenmesi, gece vakti işlenmesinin ağırlaştırıcı neden olarak düzenlenmemesinin bir eksiklik olduğu yönündeki görüş için bkz. Kocasakal, s. 118.

${ }^{107}$ Yenerer Çakmut, s. 70.

${ }^{108}$ Parlar - Hatipoğlu, s. 1935; Yenerer Çakmut, s. 71; Ekici Şahin, "Huzur ve Sükûnunu”, s. 43. Suça teşebbüsün mümkün olmadığına ilişkin görüş için bkz. Kocasakal, s. 143 ; Şen, s. 520. 
içinde ve çok uzun sayılamayacak zaman aralıklarıyla en az iki kez tekrarlanması veya mağdurun, failin davranışlarını onaylamadığını, bu davranışların yapılmasını istemediğini bildirmesine veya rızasızlığını açıkça veya zımnen ortaya koymasına rağmen, istenmeyen bu davranışın birden fazla defa tekrarlanması gerekir. Mağdurun huzur ve sükûnunun bozulmasının bir netice olarak aranmadığ yapılmasına rağmen mağdurun rahatsız olmaması durumunda fiilin teşebbüs aşamasında kaldığından bahsetmek doğru değildir. ${ }^{110} \mathrm{Bu}$ nedenle kişilerin huzur ve sükûnunu bozma suçuna teşebbüs, failin birinci davranışı gerçekleştirmesinden sonra, ancak sonraki davranışı gerçekleştirmesinden önce mümkün olabilir. Doktrinde, bir kez kapı ziline basıp kaçtıktan sonra zilin bozulması üzerine, failin zile birkaç kez daha basmasına rağmen zilin çalmaması durumunda, suçun teşebbüs aşamasında kaldığı ifade edilmektedir. ${ }^{111}$ Kanaatimizce, bu halde de suçun icrası için elverişli hareketler bulunmadığından, suçun teşebbüs aşamasında kaldığını ileri sürmek mümkün olmamalıdır. Henüz ısrar düzeyine varmamış tipik hareketlerde, failin huzur ve sükûnunu bozma kastının tespiti çok zor olacağından, uygulamada bu suça teşebbüsün sınırlı hallerde mümkün olabileceğini düşünüyoruz.

TCK m. 35'te kişinin işlemeyi kastettiği bir suçu elverişli hareketlerle doğrudan doğruya icraya başlaması arandığı için, vasıtanın elverişsizliği veya maddi konunun yokluğu halinde işlenemez suç söz konusu olacaktır. Doktrinde elverişli olmayan teşebbüs olarak da adlandırılan işlenemez suç kavramı, bir ceza kanunu hükmünü ihlale yönelmiş olmasına rağmen, ya hareketin ihlal edilmek istenen suçu karakterize eden zarar veya tehlikeyi meydana getirmeye elverişli olmaması veya hareketin konusunun bulunmaması nedeniyle başarısız kalan bir davranış olarak tanımlanabilir. ${ }^{112}$ Örneğin, sağır veya dilsiz birinin huzur ve sükûnunu bozmak isteyen failin, mağdurun bu özel durumunu bilmeksizin sürekli olarak gürültü yapmas1 halinde, gerçekleştirilen hareketler mağdurun ihlal edilmek istenen hukuksal değerini tehlikeye sokmaya elverişli değildir. Ancak, sağır ve dilsiz birinin

${ }^{109}$ Kişilerin huzur ve sükûnunu bozma suçunda, hareketin mağdurun bilgi ve algısına ulaşmasının netice olarak arandığı ve bu hususun suçun somut tehlike suçu olmasının bir gereği olduğu hakkında bkz. Kocasakal, s. 138-139.

110 Özbek - Kanbur - Doğan - Bacaksız - Tepe, s. 445.

${ }^{111}$ Ekici Şahin, "Huzur ve Sükûnunu”, s. 43.

112 Güngör, Hata, s. 122. 
huzur ve sükûnu, yüzüne 1şık tutulması, mektup veya elektronik posta veya kısa mesaj gönderilmesi gibi başka eylemlerle bozulabilir. $\mathrm{Bu}$ açıdan kullanılan vasitalar, amaçlanan hukuksal değer ihlalini gerçekleştirmeye elverişli olduğunda, TCK m. 35 gereğince kişilerin huzur ve sükûnunu bozma suçuna icra hareketlerine başlandığının kabul edilmesi gerekir. ${ }^{113}$

\section{B. İSTTIRAK}

Kişilerin huzur ve sükûnunu bozma suçu, iştirak açısından bir özellik arz etmemektedir. Söz konusu suç, özgü suç olmadığından, suça müşterek faillik, azmettirme veya yardım etme biçiminde iştirak edilmesi mümkündür. Fail, kusur yeteneğine sahip olmayan bir çocuğu veya akıl hastasını, suçu işlemekte araç olarak kullanabilir. TCK m. 37/2 anlamında dolaylı failliğin şartlarının bulunduğu bu durumda, dolaylı fail, araç olarak kullandığ akı1 hastasına, mağduru sirf huzur ve sükûnunu bozmak amaciyla israrla takip ettirebileceği gibi; gürültü yapmaları veya mağdurun ziline basıp kaçmaları ${ }^{114}$ veya camına taş atmaları için çocukları da araç olarak kullanabilir. $\mathrm{Bu}$ halde dolaylı fail, başkasına işlettiği fiilden fail olarak sorumludur. ${ }^{115}$

\section{C. İÇTiMA}

\section{Zincirleme Suç}

Suçların içtimaı konusunda, kişilerin huzur ve sükûnunu bozma suçuna vücut verebilecek hareketlerin, bir suç işleme kararının icrası kapsamında aynı mağdura karşı işlenmesi halinde zincirleme suçun oluşup oluşmayacağ 1 olayın şartlarına göre değerlendirilmelidir. Bu suçta seçimlik hareketlerin ısrar boyutuna varacak düzeyde tekrarının aranması, TCK m. 43/1 kapsamındaki zincirleme suçun oluşup oluşmadığının tespitini zorlaştırmaktadır. Arada kesinti olmaksızın birden çok defa gerçekleştirilen hareketler, tek bir huzur ve sükûnu bozma suçuna sebebiyet verecektir. ${ }^{116}$

${ }^{113}$ Ekici Şahin, "Huzur ve Sükûnunu”, s. 45.

114 Gülşen, s. 15.

115 Artuk - Gökcen - Yenidünya, s. 644.

116 "Sirf huzur ve sükûnunu bozmak maksadiyla bir kimseye ısrarla telefon edilmesi, 5237 sayılı TCK'nın 123. maddesinde düzenlenen kişilerin huzur ve sükûnunu bozma suçunun unsuru olup, aynı kanunun 43. maddesinin uygulanamayacağının gözetilmemesi ..." (Yargıtay 2. CD. 4043-7759, 30.05.2007) Aktaran: Parlar - Hatipoğlu, s. 1937. "Sanığın, 
Ancak mağdurun şikâyeti sonrası, fail hareketlerine bir suç işleme kararının icrası kapsamında devam ederse, zincirleme suç söz konusu olacaktır. Fail hakkında şikâyet üzerine dava açılmış ve kesintiye rağmen davranış devam ettirilmişse, artık ayrı bir suçun varlığını kabul etmek gerekir. ${ }^{117}$ Örneğin, kişinin huzur ve sükûnunu bozmak amaciyla kişiye bir hafta boyunca telefon edildikten sonra mağdurun savcılığa başvurması, ancak soruşturma devam ederken veya kovuşturma başladıktan sonra ${ }^{118}$ failin mağduru aynı suçu işleme kastıyla yeniden aramaya devam etmesi halinde, Kanun hükmü iki kez ihlal edilmiş olur. Ancak oluşan bu iki suç arasında, suç işleme kararında birlik söz konusuysa zincirleme suç hükümleri uygulanır. ${ }^{119}$ Yargıtay'ın bazı kararlarında bu suçun zincirleme suç biçiminde işlenemeyeceği ifade edilmektedir. ${ }^{120}$

Sanık hakkında bir defa kişilerin huzur ve sükûnunu bozma suçundan dolayı hüküm kurulduktan sonra, aynı mağdura karşı huzur ve sükûnu bozmak maksadiyla kanunda yer alan seçimlik hareketlerin gerçekleştirilmesi halinde, bir suç işleme kararının bulunduğunu iddia etmek mümkün olmamalıdır. ${ }^{121} \mathrm{Bu}$ halde, fail tarafından hükümden sonra 1srarla gerçekleştirilen hareketler yeni bir suça vücut vermelidir. ${ }^{122}$

günün değişik saatlerinde ve kısa aralıklarla olmak üzere katılanı telefonla birçok kez arayarak hiç konuşmadan sesini dinleyip telefonu kapatması ya da telefonu çaldırıp kapatması şeklinde gerçekleşen olayda, sanığın katılanı birçok kez aramasının, suçun 'ısrarla yapılması' unsurunu oluşturduğu, somut olayda bir kişiye karşı aynı suçun birden fazla işlenmesi durumunun söz konusu olmadı̆̆ ve TCK'nın 43. maddesinin uygulama koşullarının bulunmadı̆̆ gözetilmeden, hatalı değerlendirme yapılarak sanık hakkında TCK'nın 43. maddesinin uygulanması suretiyle fazla cezaya hükmolunmast ...” (Yargitay 2. CD. E. 2011/31120, K. 2013/18153, 03.07.2013) Aktaran: Yaşar - Gökcan - Artuç, s. 4084.

117 Yenerer Çakmut, s. 72.

${ }^{118}$ Kovuşturmanın başlamasının, zincirleme suçta bir suç işleme kararını ortadan kaldırmayacağına ilişkin bkz. Yalçın Sancar, s. 112.

${ }^{119}$ Ekici Şahin, "Huzur ve Sükûnunu”, s. 45; Gülşen, s. 16.

120 “Sanığın mağdure Emine'yi telefonla ısrarla arayarak işlediği kişilerin huzur ve sükûnunu bozma suçunun, içinde zincirleme gerçekleştirilen eylemleri de kapsadı̆̆l, birçok kez arayarak rahatsız etmenin suçun unsuru olduğu gözetilmeden, belirlenen cezanın TCK'nın 43. maddesi uyarınca arttırlmast ..." (Yargitay 14. CD. E. 2011/6444, K. 2012/8973, 25.09.2012) Erişim: http://www.kazanci.com/kho2/ibb/files/14cd-2011-6444.htm (04.04.2019)

${ }^{121}$ Hükmün verilmesinin bir suç işleme kararını ortadan kaldıracağı hakkında bkz. Yalçın Sancar, s. 113.

122 Gülşen, s. 16. 
Kişilerin huzur ve sükûnunu bozma suçunun, TCK m. 43/2 anlamında tek bir hareketle birden çok kişiye karşı da işlenebilmesi mümkündür. ${ }^{123}$ Ancak bunun için, bu hareketlerin birden çok kişinin huzur ve sükûnunu bozmak amacıyla yapıldığının fail tarafından bilinmesi gerekir. Örneğin, evinin alt katını kiralamış olan öğrencilerden hoşlanmayan failin, öğrencilerin huzur ve sükûnunu bozmak için sürekli gürültü yapması veya öğrencilerin ziline ısrarla basıp kaçması halinde, bu suçun zincirleme suç biçiminde işlendiği kabul edilmelidir. ${ }^{124}$

\section{Fikri İçtima}

Failin gerçekleştirdiği tek bir fiilin, kanunun farklı hükümlerini ihlal etmesi halinde, TCK m. 44 uyarınca, faile bunlardan en ağır cezayı gerektiren suçtan ötürü ceza verilmesi gerekmektedir.

Kişilerin huzur ve sükûnunu bozma suçu açısından, seçimlik hareketlere ve failin suç kastına göre hangi suçların oluştuğunun her somut olay bakımından değerlendirilmesi zorunludur. Yargı kararlarında da görüldüğü üzere, komşusunun evinin yakınında bulunan ağaca tırmanıp yatak odasının gözetlenmesi olayında, failin kastına göre hareket edilmesi ve bu açıdan TCK m. 134'teki özel hayatın gizliliğini ihlal suçundan dolayı cezai sorumluluğun belirlenmesi doğru olacaktır. ${ }^{125}$

\footnotetext{
123 "Sanı̆̆ın aralarında ögrenci taşıma rekabeti bulunan başka bir kooperatife ait minibüsün önüne geçip, içinde ögrencilerin bulunduğu minibüsün şoförü ile bu konu yüzünden tartıştı̆̆ı, ögrencilere kendisine ait minibüse binmeyi telkin ettiği, tartışmalar sebebiyle ögrencilerin ders ve psikolojik durumlarının olumsuz etkilendiğinin iddia edildiği olayda, sanığa yüklenen kişilerin huzur ve sükûnunu bozma suçu ögeleri yönünden oluşmadı̆̆ halde, sanık hakkında atılı suçtan hükümlülük kararl verilmesi, 5237 sayılı TCK'nın 123. maddesinde düzenlenen kişilerin huzur ve sükûnunu bozmak suçunun aynı yer veya ortamda bulunan kişilere karşı işlenmesi halinde de eylemin tek suç olacağl gözetilmeden aynı kanunun 43. maddesi uyarınca artırım yapılarak sanığa fazla ceza verilmesi ..." (Yargitay 2. CD. E. 2010/37135, K. 2012/42126, 26.09.2012) Erişim: http://www.kazanci.com/kho2/ibb/files/2cd-2010-37135.htm (04.04.2019); "Sanı̆̆ın eyleminin 'katılanların ikametinde bulunan telefonu ve katılan Ayşenur'un işyeri telefonunu birden fazla kez ve ısrarla arayarak katılanları rahatsız ettiği' biçiminde olduğunun kabul edilmesi karşısında, TCK'nun 43/2. maddesinin uygulanıp uygulanamayacağının tartışılmaması" (Yargitay 4. CD. E. 2013/4800, K. 2014/12806, 21.04.2014) Aktaran: Kocasakal, s. 144, dn. 85.

${ }^{124}$ Ekici Şahin, "Huzur ve Sükûnunu”, s. 46.

125 Aynı yönde görüş için bkz. Kocasakal, s. 129.
} 
Mağdurun huzur ve sükûnunu bozmak maksadıyla telefonda hakaret veya tehdit içerikli sözler söylenmesi halinde, failin cezai sorumluluğunun nasıl belirleneceği tartışmalıdır. Yargıtay'ın bazı kararlarında, bu durumda gerçek içtima hükümlerinin uygulanması gerektiği belirtilmiştir. ${ }^{126}$ Bazı kararlarda ise fikri içtima gereği, hakaret ve tehdit suçu haricinde faile kişilerin huzur ve sükûnunu bozma suçundan dolayı ceza verilemeyeceğine hükmedilmiştir. ${ }^{127}$ Öğretideki bir görüş, kişilerin huzur ve sükûnunu bozma suçunun genel ve tamamlayıcı nitelikte bir suç olduğundan hareketle, fiilin başka suçlara vücut vermesi durumunda, ayrıca kişilerin huzur ve sükûnunu bozma suçundan dolayı ceza verilemeyeceği yönündedir. ${ }^{128}$ Bir başka görüş ise, hakaret, tehdit ve kişilerin huzur ve sükûnunu bozma suçlarının birlikte işlenmesi durumunda gerçek içtima hükümlerinin uygulanması gerektiği yönündedir. ${ }^{129}$ Kanaatimizce, bu noktada suçun manevi unsuruna ilişkin açıklamalarımız da dikkate alınarak, kast kurallarına göre failin cezai sorumluluğu belirlenmeli ve münhasıran kişilerin huzur ve sükûnunu bozma amacıyla hareket ettiğinin saptanması halinde bu suçtan dolayı hüküm kurulmalıdir.

Failin davranışları, cinsel taciz suçuna vücut verebilecek birtakım cinsel çağrışımları içeriyorsa bu halde cinsel taciz suçunun oluşup oluşmayacağ değerlendirilmelidir. TCK m. 105'te cinsel amacın yani failin özel kastının aranması karşısında, ${ }^{130}$ hem huzur ve sükûnu bozma amacının hem de cinsel amacın bir arada bulunabileceğini iddia etmek çelişkili olacaktır. ${ }^{131} \mathrm{Bu}$

126 "Sanı̆̆ı̆n yakınan Nurcan Yılmaz'a yönelik sövme eylemine ilişkin olarak yakınmadan vazgeçilmesi nedeniyle kamu davasının düşürülmesi ve tehdit suçlarından sanık savunması alınarak, kanıtların toplanıp tartışılması, sonucuna ve kanıtların kabul edilip biçimine göre sanığın hukuksal durumunun belirlenmesi gerekirken; eylemlerin bütünüyle huzur ve sükûn bozma suçunu oluşturduğu kabul edilerek hüküm kurulması ..." (Yargıtay 4. CD. 3540-8505, 31.10.2007) Aktaran: Parlar - Hatipoğlu, s. 1937. Karş1 görüş için bkz. Ekici Şahin, "Huzur ve Sükûnunu”, s. 46.

127 "....saniğın telefonla arama ve mesaj çekme suretiyle katılana hakaret ve tehditlerde bulunduğu kabul edildiğinden fikri içtima kuralları gereğince ayrıca huzur ve sükunu bozma suçunun oluşmayacağı gözetilmeden” (Yargitay 4. CD. E. 2012/16788, K. 2013/30595, 03.12.2013) Aktaran: Kocasakal, s. 131, dn. 53.

${ }^{128}$ Kocasakal, s. 131.

${ }^{129}$ Şen, s. 521.

130 Taner, s. 376. Yazara göre cinsel taciz suçunda kanun koyucunun özel kastı aramasının nedeni, cinsel taciz suçunun diğer suçlardan ayırt edilmesinin sağlanmasıdır.

131 "Șehirlerarası otobüste yolculuk yapan sanığın, uzun süre mağdureyi bakışları ile rahatsız ettikten sonra arkasindaki koltuğa oturarak önce koltuğu sarstığl, sonra da cam kenarından kolunu uzatarak mağdurenin koluna temas ettiği, daha sonra da 'seni tanımak 
açıdan aynı fiilin, cinsel taciz suçu ile birlikte kişilerin huzur ve sükûnunu bozma suçuna vücut vermesi mümkün olmadığından, failin kastı dikkate alınarak hangi suçtan sorumlu tutulacağının belirlenmesi gerekir. ${ }^{132}$ Somut olayda failin kastına göre, ya cinsel taciz ya da kişilerin huzur ve sükûnunu bozma suçundan dolayı sorumluluk gündeme gelecektir. ${ }^{133}$ Yargıtay, herhangi bir cinsel çağrışımı içermeyen ve kişilerin huzur ve sükûnunu bozma suçuna vücut verebilecek bazı davranışları, cinsel taciz suçu kapsamında görmekte ve isabetsiz kararlar vermektedir. ${ }^{134}$

Failin, ilgili kanunlarda belirlenen yükümlülüklere aykırı olarak, başka bir kimsenin zarar görmesine elverişli bir şekilde gürültüye neden olması halinde, TCK m. 183'te düzenlenen gürültüye neden olma suçu oluşacaktır. Aşağıda da bahsedileceği üzere bu suç, mağdurun belirli bir kimse olmaması, ${ }^{135}$ özel kastın aranmamas1, ${ }^{136}$ ssrarın gerekmemesi ve gürültünün

isterim, siz de isterseniz ... numarayı arayın' yazılı kă̆ıdı vermeye çalıştı̆̆l, saniğın suçlamaları kabul etmemekle birlikte kăgıtta yazılı telefon numarasının kendisine ait olduğunu ve yazıyı da kendisinin yazdiğını ikrar ettiği anlaşılmakla; mağdurun ... ilk defa otobüste gördüğ̈̈ sanı̆̆a iftira atmasinı gerektirecek bir neden olmadı̆g gibi ... sanığın 5237 sayll TCK'nin 123 ve 105/1 maddesine göre cezalandırlmasl yerine ... beraat kararl verilmesi ..." (Yargitay 4. CD. E. 2012/28642, K. 2013/881, 21.01.2013) Aktaran: Yaşar - Gökcan - Artuç, s. 4073, dn. 2488.

${ }^{132}$ Yargıtay'ın bu konuda fikri içtima kurallarının uygulanması gerektiğine ilişkin kararları bulunmaktadır. "Sanığın, katılanlara ait telefonu sürekli ve ısrarla arayarak telefonu açan müştekilerden Nimet A.'ya hitaben 'seni çok seviyorum, seninle arkadaşlı yapmak istiyorum, gününün bir saatini bana ayır, yalvarırım ne olur' şeklinde sözler söyleyerek, bir fiil ile hem cinsel taciz hem de kişilerin huzur ve sükûnunu bozma suçlarını işlediği dosya kapsamıyla anlaşılan sanığın TCK'nın 44. maddesi karşısında bunlardan sadece en ăğr cezayı gerektiren 5237 sayıl TCK'nın 105/1 maddesinde tanımlanan cinsel taciz suçundan sorumlu tutulması gerektiği gözetilmeden, ayrıca kişilerin huzur ve sükûnunu bozma suçundan da mahkûmiyetine karar verilmesi ..." (Yargitay 14. CD. E. 2011/10192, K. 2012/1010, 08.02.2012) Aktaran: Yaşar - Gökcan - Artuç, s. 4090.

${ }^{133}$ Aynı yönde görüş için bkz. Yenerer Çakmut, s. 88.

134 "Daha önceden sanığl tanımayan ve sanı̆̆a iftira atması için bir neden bulunmayan mağdurenin aşamalardaki istikrarlı beyanları ve bu beyanları doğrulayan tanık Emine'nin anlatımları, sanık tarafindan mağdureye verilen telefon numarası yazılı olan kağıt parçası, sanı̆̆ın tevilli ikrarı ile tüm dosya kapsamından; olay günü saat 13.00 siralarında evine doğru giden mağdurenin arkasindan arkadaşıyla birlikte gelip, mağdureyi evine kadar ısrarla takip eden ve yazdı̆̆ kă̆ıdı mağdureye verip 'beni bu numaradan ararsın' şeklinde sırnaşıkça hareketlerde bulunan sanığın eylemi cinsel taciz suçunu oluşturduğu halde, ... sanı ğın beraatine karar verilmesi ..." (Yargitay 14. CD. E. 2011/7453, K. 2012/3116, 15.03.2012) Erişim: http://www.kazanci.com/kho2/ibb/files/14cd-20117453.htm (04.04.2019)

135 Yenerer Çakmut, s. 97.

${ }^{136}$ Yenerer Çakmut, s. 114. 
başkalarının sağlığının zarar görmesi bakımından elverişli olmasının aranması noktalarında kişilerin huzur ve sükûnunu bozma suçundan ayrışmaktadır. Bu açıdan, her somut olayda failin kastı, belli bir mağduru hedef alıp almadığı araştırılarak kişilerin huzur ve sükûnunu bozma suçunun mu gürültüye neden olma suçunun mu oluştuğu tespit edilmelidir.

Öğretideki bazı yazarlar ${ }^{137}$ ve Yargıtay tarafından, kişilerin huzur ve sükûnunu bozma suçu, genel ve tamamlayıcı nitelikte görülmekte ${ }^{138}$ ve gerçekleştirilen hareketlerin başka bir suça ${ }^{139}$ vücut vermesi halinde gerçek içtima hükümlerinin uygulanmayacağ 1 belirtilmektedir. ${ }^{140}$ Kanaatimizce,

${ }_{137}$ Bkz. Kocasakal, s. 131.

138 "Sanı̆̆ın, katılanların cep telefonlarına gönderdiği mesajlarla tehdit, hakaret suçlarını işlediğinin kabul edilmesi karşısında, genel ve tamamlayıcı nitelikte olan kişilerin huzur ve sükûnunu bozma suçundan ayrıca cezalandırılamayacağının gözetilmemesi ...” (Yargıtay 4. CD. E. 2011/15874, K. 2013/11896, 17.04.2013) Aktaran: Yaşar - Gökcan - Artuç, s. 4071, dn. 2478.

139 “'Sanık Şaziye C. ’ın, katılan Aydın K. ’ın gıyabında, katılanın eşi tanık Huri K. 'ya söylediği 'kocanın başka kadınlarla ilişkisi, başka kadınlardan çocuğu var. Kocanın kız kardeşim ile ilişkisi var, kocan şerefsiz' biçimindeki sözlerin, katılanın eşinin yanı sıra katılanın kendisinin onur, şeref ve saygınlı̆̆ını da rencide edici nitelikte olduğu, katılana yönelik hakaretin olay yerinde bulunan taniklar Huri K., Nermin K. Ve Hatice K. tarafindan da duyulmuş olması nedeniyle sanığın gıyapta hakaret suçuna yönelik ihtilat unsurunun oluştuğu gözetilmeden, suç vasfinın değerlendirilmesinde yanılgıya düşülerek sanığın eyleminin kişilerin huzur ve sükununu bozma suçunu oluşturduğu kabul edilerek yazılı biçimde karar verilmesi ...” (Yargıtay 2. CD. E. 2011/29526, K. 2013/15794, 12.06.2013) Aktaran: Yaşar - Gökcan - Artuç, s. 4083. "Somut olayda otelin restoran bölümünde ayağa kalkarak elindeki boş bira şişesini beton kolonlara vurup kıran ve cam kıriğ ile tişörtünü kaldırarak vücuduna zarar veren sanığın eyleminin sadece mala zarar verme suçunu oluşturacağl gözetilmeden, sanık hakkında ayrıca kişilerin huzur ve sükûnunu bozma suçundan da mahkûmiyet hükmü kurulması ..." (Yargitay 9. CD. E. 2012/1154, K. 2013/1345, 24.01.2013) Aktaran: Yaşar - Gökcan - Artuç, s. 4084.

140 "Sanığın, katılanla aralarındaki evlilik dışı ilişsi sonucu doğduğunu iddia ettiği çocuk nedeniyle, kullandiğ telefonla katılana ait telefonu birden fazla arayarak ve mesajlar çekerek para talebinde bulunduğu, isteğinin yerine getirilmemesi halinde bu durumu iş ve aile çevresine yayacağı tehdidinde bulunma biçimindeki eylemlerinin bir bütün halinde zincirleme şekilde şantaj suçunu oluşturduğu gözetilmeden, bu suçun yanı sıra TCK'nın 123. maddesinde belirlenen kişilerin huzur ve sükûnunu bozma suçundan da hüküm kurularak saniğa fazla ceza tayini ..." (Yargitay 4. CD. E. 2011/6680, K. 2011/12404, 11.07.2011) Aktaran: Yaşar - Gökcan - Artuç, s. 4083. "Sanı̆̆ın, adına kayıtlı cep telefonu ile 12.02.2006 günü mağdurenin kullandiğl cep telefonuna 9 adet cinsel taciz ve hakaret içeren mesajlar göndermesi ve aynı gün mağdureyi aynı kastla 12 defa da araması şeklinde gerçekleşen olayda saniğın eylemlerinin TCK'nın 44. maddesine nazaran bir bütün olarak zincirleme şekilde cinsel taciz ve zincirleme şekilde hakaret suçların oluşturduğu, sanığın eyleminin başkaca suçu oluşturması durumunda 'kişilerin huzur ve sükûnunu bozma suçunun' oluşmayacă̆ı gözetilmeden yazılı şekilde mahkûmiyetine 
suçun genel ve tamamlayıcı nitelikte bir suç olduğunun Kanun'da açıkça belirtilmemesi (TCK m. 257'de olduğu gibi) karşısında, bu türden bir çıkarımda bulunmak isabetli değildir. Bu nedenle her somut olayda, failin gerçekleştirdiği fiilinde hangi suçu işlemeyi kastettiğinin saptanıp, ona göre hüküm kurulması gereklidir.

\section{SUÇUN BENZER SUÇ VE KABAHATLERDEN FARKI}

\section{A. 765 SAYILI MÜLGA TCK'DAKİ DÜZENLEME}

Kişilerin huzur ve sükûnunu bozma suçuna vücut verebilecek fiiller, 765 sayılı Mülga TCK'nın "Kabahatler" başlıklı üçüncü kitabının, "Ammenin Nizamına Müteallik Kabahatler" adlı birinci babının, "Halkı Rahatsız Eden Hareketler" başlığı altındaki yedinci faslında, 546 ve 547. maddelerinde düzenlenmişti. Buna göre 546. madde:

"Her kim, gürültü veya velvele ile mutat hilafi olarak çan ve alatı saire çalarak yahut kanun ve nizam ahkâmına muhalif surette gürültülü bir meslek ve sanat icra eyliyerek halkın veya meclis ve mahfillerin meşguliyet veya huzur ve rahatın ihlal ederse on beş liraya kadar hafif cezayı nakdiye mahkûm olur.

Bu fiil gece yarısından iki saat evvelinden sonra işlenirse hafif cezayı nakdi otuz liraya kadardır.

Mükerrirler hakkinda birinci fikrada muharrer ahvalde otuz ve ikinci fikrada muharrer halde elli liraya kadar hafif cezayi nakdi hükmolunur" şeklinde düzenlenmişti.

Kanun'un 547. maddesi ise:

"Her kim, itidal ve muvazene haricinde veya çirkin ve ayıp görünen sair herhangi bir hal ile başkasını alenen incitir veya huzur rahatını ihlal ederse on beş güne kadar hafif hapse veya otuz liraya kadar hafif cezayı nakdiye mahkûm olur" şeklindeydi.

Mülga TCK döneminde bu filllerin kabahat olarak düzenlenmesinde, halkın huzur içinde yaşaması ve dengeli bir ortamın sağlanması amacı üstün

hükmedilmesi ...” (Yargitay 14. CD. E. 2011/19824, K. 2013/707, 29.01.2013) Aktaran: Yaşar - Gökcan - Artuç, s. 4085. 
tutulmuştur. $\mathrm{Bu}$ açıdan hukuki konunun; kişilerin değil, halkın huzur ve rahatının korunması olduğu kabul ediliyordu. ${ }^{141}$

546. maddedeki kabahatte maddi unsur açısından, "velvele, çan ve saireden” kaynaklı gürültü cezalandırılıyordu. Öğretideki yazarlar, buna şark1 ve bandoları da dahil etmekteydi. 547. maddede ise, halkın huzur ve rahatının çirkin hareketlerle bozulması maddi unsur kapsamındaydı. Yargı kararlarına bakıldığında benzer bir şekilde, evin pencere camının tıklatılması $1,{ }^{142}$ mağduru araçla bir süre takip etmek, ${ }^{143}$ far yakmak ve korna çalmak, ${ }^{144}$ birçok kez telefonla arayıp konuşmadan kapatmak, ${ }^{145}$ avlu duvarına çıkıp evin içinin gözlenmesi ${ }^{146}$ gibi fiiller bu madde kapsamında görülmüştür. Ancak mülga TCK'daki düzenlemelerde bu davranışların 1srarla gerçekleştirilmesi aranmamaktaydi.

Mülga TCK'daki düzenlemenin, 5237 say1lı TCK m. 123'teki düzenlemeden manevi unsur açısından da farklılaştığı görülmektedir. Zira

${ }^{141}$ Faruk Erem, Türk Ceza Kanunu Şerhi Özel Hükümler, C. 3, B. 1, Ankara 1993, s. 2610.

142 "Yol üzerinde bulunan evin, pencere camını tıklatmaktan ibaret olan sanığın eyleminin TCK'nın 547. maddesine uygun itidal ve muvazene dışı hareket suçunu oluşturduğu gözetilmeden ayrıca mesken masuniyetini ihlale teşebbüs suçundan da hükümlülüğüne karar verilmesi ..." (Yargitay 4. CD. E. 1982/345, K. 1982/794, 09.02.1982) Erişim: http://www.kazanci.com/kho2/ibb/files/4cd-1982-345.htm (04.04.2019)

143 "Sanı̆̆ın kullanmakta olduğu aracı ile yolda gördüğ̈̈ müştekiyi bir süre takip etmek suretiyle huzurunu bozduğu, edep ve nezahat hislerini rencide edecek bir davranışta bulunmadĭ̆ anlaşılmasına göre eylemine uyan TCK'nın 547. maddesi yerine yazılı şekilde hüküm tesisi ...” (Yargıtay 5. CD. E. 1991/599, K. 1991/795, 19.02.1991) Erişim: http://www.kazanci.com/kho2/ibb/files/5cd-1991-599.htm (04.04.2019)

144 "Sevk ve idaresindeki otomobiliyle gece vakti müstekilerin evinin önünde durarak far yakıp söndüren ve korna çalmak suretiyle de müştekilerin rahat ve huzurlarını ihlal eden sanı̆̆ın, eylemi sabit olup, TCK'nın 547. maddesinde yazılı suçu oluşturduğundan ... yazılı şekilde beraat karart verilmesi ...” (Yargitay 5. CD. E. 1991/3210, K. 1991/4292, 16.10.1991) Erişim: http://www.kazanci.com/kho2/ibb/files/5cd-1991-3210.htm (04.04.2019)

145 "Müştekinin ev telefonunu birçok kez arayıp bir şey söylemeden kapatmak suretiyle rahatsı ettiği PTT tespit tutanăğ, müssteki ve eşinin anlatımları ile kanttlanan sanı̆̆ı̆ eyleminin TCK'nın 547. maddesine uyan itidal ve muvazene harekette bulunmak suçunu oluşturduğunun gözetilmemesi ..." (Yargıtay 5. CD. E. 2003/450, K. 2003/1533, 27.03.2003) Aktaran: Nihat Meydan - Fadime Yapal, İçtihatlı Türk Ceza Kanunu, C. 2, B. 1, İstanbul 2004, s. 2071.

146 "Sanığın, katılanın avlu duvarı üzerine çıkıp eve bakmaktan ibaret eyleminin TCK'nın 547. maddesinde öngörülen suçu oluşturacağı düşünülmeden, anılan yasanın 193/2 maddesiyle hüküm kurulması ...” (Yargıtay 4. CD. E. 1993/8133, K. 1993/8769, 14.12.1993) Erişim: http://www.kazanci.com/kho2/ibb/files/4cd-1993-8133.htm (04.04.2019) 
mülga TCK'daki düzenlemede failin, huzur ve sükûnu bozma özel kastıyla hareket etmesi de gerekli değildi.

Son olarak, önceki düzenlemede suç re'sen takip edilirken; 5237 say1lı TCK'daki düzenlemede suçun soruşturulması ve kovuşturulması şikâyet şartına bağlanmıştır. ${ }^{147}$

\section{B. STALKING}

Kelime anlamı itibariyle stalking, bir kimsenin rahatsız edilmesi veya zarar görmesi amacıyla bir başka kimse tarafından gizlice ve ısrarlı biçimde takip edilmesidir. ${ }^{148} \mathrm{Bu}$ kavram ilk zamanlarda; Amerika, Avustralya, Kanada ve İngiltere'de magazin gazeteciliğinde kamuoyu tarafından tanınan ünlü kişilerle iletişim kurma gayretinde olan takıntılı hayranların takip etme çabasını ifade ediyordu. ${ }^{149}$ Daha sonraları, aynı veya birbirinden farklı, ancak sürekli tekrarlanan fiillerle mağdurun takip, tehdit ve taciz edilmesi ve bu suretle muhatap üzerinde korku, endişe, huzursuzluk ve paniğe yol açılmasını ifade etmek için kullanılmıştır. ${ }^{150}$ En sık rastlanan stalking eylemlerinin, istenmeyen telefon aramaları ve çağrıları yapmak, istenmeyen mektup ve e-postalar göndermek, mağduru takip etmek ve gözetlemek, bir sebep olmaksızın sürekli mağdurun karşısına çıkmak, mağduru değişik yerlerde beklemek, mağdura isteği dışında hediye, çiçek ve benzeri eşya göndermek, mağdur hakkında internette veya kamuya açık yerlerde veya başka yollarla asılsız dedikodular yaymak olduğu saptanmıştır. ${ }^{151}$

Alman Ceza Kanunu'nun 238. maddesine göre, bir kişi diğerinin 1srarla yakın alanında bulunursa, iletişim vasıtaları veya diğer araçlarla kendisi veya üçüncü kişiler aracılığıla onunla iletişim kurmayı denerse, onun kişisel bilgilerini kötüye kullanarak mal veya hizmet siparişinde bulunur veya üçüncü kişilerin bundan dolayı onunla iletişime geçmesine sebep olursa, onun veya yakınının yaşamını, vücut dokunulmazlığını, sağlığını veya özgürlügünü tehdit eder veya buna benzer başka bir davranışta bulunursa ve

${ }^{147}$ Yenerer Çakmut, s. 52.

148 Bryan Garner, Black's Law Dictionary, Second Pocket Edition, 2001, s. 660.

${ }^{149}$ Yenerer Çakmut, s. 79.

${ }^{150}$ Yenerer Çakmut, s. 80.

${ }^{151}$ Ahmet Türkmen, "Yeni Bir Hukuki Olgu Olarak Israrl Takip ve Taciz (Stalking) ve Bunun Türk Medeni Hukuku Bakımından Değerlendirilmesi”, in. DEÜHFD, C. 11, İzmir 2010, s. 1391. 
bununla kişinin yaşam biçimi ağır derecede ihlal edilirse, fail üç yıla kadar hapis veya para cezasıyla cezalandırılır. ${ }^{152}$ Eğer fail, mağduru, mağdurun aile mensuplarından birini veya mağdurun yakınlarından birini, işlediği fille ölüm tehlikesi veya sağlığının ağır bir şekilde bozulması tehlikesine düşürürse üç aydan beş yıla kadar hapis cezasıyla cezalandırılır. Failin fiili sonucunda, mağdur veya onun bir aile mensubu ölürse, bu takdirde ceza bir y1ldan on yıla kadar hapis cezasıdır. Bu maddede düzenlenen suçun basit hali şikâyete tabi tutulmuştur. ${ }^{153}$ Kanunda yer alan, "buna benzer davranışlarda bulunmak" ifadesinden, stalking suçuna vücut verebilecek olan eylemlerin sınırlı bir şekilde sayılmadığı anlaşılmaktadır.

Avusturya Ceza Kanunu'nun 1srarlı takibi düzenleyen 107/a hükmüne göre, bir kişi ciddi anlamda ve uzun bir süre diğerinin yakın alanında bulunmak, onunla tele-iletişim ya da diğer iletişim vasıtaları veya üçüncü bir kişi aracılı̆̆ıyla iletişim kurmak, onun kişisel bilgilerini kullanarak mal ve hizmet siparişinde bulunmak, üçüncü kişilerin kişisel bilgilerini kullanarak onunla iletişim kurmasına sebep olmak suretiyle diğerinin yaşamını ihlal ederse 1srarlı takip eyleminin varlığından söz edilir ve fail bir yıl hapis cezasıyla cezalandırılır. ${ }^{154}$

Hukukumuzda "1srarlı takip" ile ilgili olarak 6284 say1lı Ailenin Korunması ve Kadına Karşı Şiddetin Önlenmesine Dair Kanun'un 1. maddesinin 1. fikrasında, "Bu Kanunun amacl; şiddete uğrayan veya şiddete uğrama tehlikesi bulunan kadınların, çocukların, aile bireylerinin ve tek taraflı ısrarlı takip mağduru olan kişilerin korunması ve bu kişilere yönelik şiddetin önlenmesi amacılla alınacak tedbirlere ilişkin usul ve esaslar düzenlemektir" ş̧eklinde hüküm bulunmaktadır. Ayrıca, 6284 sayılı Ailenin Korunması ve Kadına Karşı Şiddetin Önlenmesine Dair Kanuna İlişkin Uygulama Yönetmeliği'nin 3. maddesinin 1. fikrasının (ş) bendinde tek taraflı 1srarlı takip, "Aralarında aile bağı veya ilişki bulunup bulunmadiğına

152 Türkmen, s. 1396. Alman Ceza Kanunu'ndaki ssrarlı bir şekilde izleyerek rahatsız etme suçunun, TCK m. 123 ile benzer nitelikte olduğu, tıpkı TCK m. 123'teki, "hukuka aykırı başka bir davranışta bulunma" seçimlik hareketinde olduğu gibi Alman Ceza Kanunu'ndaki düzenlemede de "sair bir fiil" hareketinin Kanun'a eklendiği, sair bir fiil ifadesinin de belirli bir içeriğe sahip olmadığı belirtilmiştir. Bkz. Feridun Yenisey Gottfried Plagemann, Alman Ceza Kanunu Strafgesetzbuch (StGB), B. 2, İstanbul 2015, s. 348, dn. 151 .

${ }^{153}$ Yenerer Çakmut, s. 82.

154 Türkmen, s. 1398-1399. 
bakılmaksızın, şiddet uygulayanın, şiddet mağduruna yönelik olarak, güvenliğinden endişe edecek şekilde fiziki veya psikolojik açıdan korku ve çaresizlik duygularına sebep olacak biçimde, içeriği ne olursa olsun, fiili, sözlü, yazılı olarak ya da her türlü iletişim aracını kullanarak ve baskl altında tutacak her türlü tutum ve davranış" olarak tanımlanmıştır. Bu açıdan ssrarlı takip nedeniyle mağdur olan kimseler için hakim, kolluk görevlileri ve mülki amirler tarafindan re'sen veya talep üzerine koruyucu ve önleyici tedbir kararları verilebilecektir.

Bunun haricinde stalking, karşılaştırmalı hukukta düzenlenenin aksine, TCK'da bağımsız bir suç tipi olarak düzenlenmiş değildir. Ancak, ısrarlı takip kapsamındaki fiillerin, TCK'da yer alan hakaret, tehdit, cinsel taciz, kişilerin huzur ve sükûnunu bozma suçlarına vücut vermesi halinde bu suçlardan ötürü failin cezalandırılabilmesi mümkündür.

\section{CINSEL TACIZ SUÇU}

5237 say11 TCK m. 105'te cinsel taciz suçu, "Bir kimseyi cinsel amaçlı olarak taciz eden kişi hakkında, mağdurun şikâyeti üzerine, üç aydan iki yıla kadar hapis cezasina veya adli para cezasina fiilin çocuğa karşı işlenmesi hâlinde altı aydan üç yıla kadar hapis cezasına hükmolunur" şeklinde düzenlenmiştir. 2. fikrada fiilin; posta veya elektronik haberleşme araçlarının sağladığı kolaylıktan faydalanmak suretiyle işlenmesi bir ağırlatıcı neden olarak öngörülmüştür.

Cinsel taciz suçu, rıza hilafına işlenen cinsel özgürlüğe karşı suçlar arasındaki en hafif ihlali teşkil etmekte ve cinsel amaçlı vücut teması gerektirmemesi nedeniyle bu bölümdeki diğer suçlardan ayrışmaktadır. ${ }^{155} \mathrm{Bu}$ suçla, cinsel saldırı boyutuna ulaşmamakla birlikte, cinsel yönden kişiyi rahatsız edici davranışlar da ayrıca cezalandırılmak suretiyle, cinsel özgürlüğün daha geniş bir çerçevede korunmasına olanak sağlanmak istenmiştir. $^{156}$

Maddi unsur açısından cinsel taciz, bir kişinin cinsel özgürlüğüne ve ahlaki duygularına yönelik, utanç duygusunu tahrip eden sözlü, yazılı ya da başka şekillerde gerçekleştirilen, bedeni teması içermeyen rahatsız edici

155 Taner, s. 349.

156 Tezcan - Erdem - Önok, s. 376. 
hareketler olarak tanımlanabilir. Ancak bu tanım öznel bir nitelik taşımakta ve her somut olayda hangi fiillerin cinsel taciz teşkil edeceği konusunda çok farklı uygulamaların ortaya çıkması mümkün gözükmektedir. Kaldı ki tacizin yöneldiği alan, herkese göre değişebilen bir duygu ve anlayış çerçevesini, bir bakış açısını yansıttığından, fiilin içeriğinin kanun koyucu tarafindan yeterince doldurulmamas1 durumunda, kanunilik unsuru bakımından çeşitli problemler ortaya çıkacaktır. ${ }^{157}$

Cinsel taciz suçu serbest hareketli bir suç olarak yazı, söz, mimik, telefon, elektronik posta, cep telefonu mesajı veya diğer vasıtalarla işlenebilir. Şehvet duygusuyla mağdura şarkı söylenmesi veya cinsel organın gösterilmesi halinde de suç oluşacaktır. ${ }^{158}$

Cinsel taciz suçu, kasten işlenebilen bir suçtur. Bu suçun oluşabilmesi için failde cinsel arzuları tatmin etme saikinin varlığı aranır. Failin bu saiki taşımaksızın gerçekleştirdiği fiil, koşulları varsa TCK'da düzenlenmiş bir başka suça vücut verebilecektir. Dolayısıyla failin özel kastının arandığı cinsel taciz suçuna vücut veren fiilin, ayrıca kişilerin huzur ve sükûnunu bozma suçuna vücut verebilmesi mümkün değildir. ${ }^{159}$

Yargitay herhangi cinsel çağrışım içermeyen ve bu suçun hukuki konusu olan cinsel özgürlüğü ihlal etmeye elverişli olmayan iltifat, ${ }^{160}$ arkadaşl1k $^{161}$ ve buluşma ${ }^{162}$ tekliflerini ${ }^{163}$ cinsel taciz suçu kapsamında

${ }^{157}$ Gülşah Kurt, "5237 Sayılı Türk Ceza Kanununda Cinsel Taciz Suçu”, in. Uğur Alacakaptan'a Armağan, C. 1, B. 1, İstanbul 2008, s. 514.

${ }^{158}$ Kurt, s. 517.

${ }^{159}$ Yenerer Çakmut, s. 88.

160 "Mağdurenin aşamalardaki samimi anlatımları, tanık Gözde’nin beyanı ve tüm dosya içeriğinden, daha önceden kendisini tanımadı̆̆ mağdurenin olay günü yanına gelen sanığın, kendisine burs temin edeceği vaadiyle onunla yakınlık sağlamaya çalıştığı, bu suretle sohbete başlayan sanığın mağdureye boş vakti olup olmadiğını sorup buluşma ve yemek teklifinde de bulunup, gözlerinin ne kadar güzel olduğu ve ne güzel bir kiz olduğu şeklinde sözler de söylemek suretiyle TCK'nın 105/1. maddesinde düzenlenen cinsel taciz suçunu işlediği sabit olduğu halde ...” (Yargıtay 14. CD. E. 2011/12504, K. 2012/6089, 29.05.2012) Aktaran: Taner, s. 372.

161 "Saniğın katılanlara ait telefonu sürekli ve ısrarla arayarak telefon açan müştekilerden Nimet A. 'ya hitaben, 'Seni çok seviyorum. Seninle arkadaşlık yapmak istiyorum. Gününün bir saatini bana ayır, yalvarırım ne olur' şeklinde sözler söyleyerek, bir fiil ile hem cinsel taciz hem de kişilerin huzur ve sükûnunu bozma suçlarını işlediği dosya kapsamıyla anlaşılan sanı̆̆ın TCK'nın 44. maddesi karşısında bunlardan sadece en ă̆ır cezayı gerektiren 5237 sayıl TCK'nın 105/1. maddesinde tanımlanan cinsel taciz suçundan sorumlu tutulması gerektiği gözetilmeden, ayrıca kişilerin huzur ve sükûnunu bozma 
değerlendirmektedir. Kanaatimizce herhangi bir cinsel çağrışımı olmayan davranışların cinsel taciz suçu kapsamında görülmesi isabetsiz olup, bu tür hallerde eğer ki failin özel kastı mevcutsa ve TCK m. 123'teki tipik hareketler 1srarla gerçekleştiriliyorsa, kişilerin huzur ve sükûnunu bozma suçundan dolayı hüküm kurulması değerlendirilebilir.

Sonuç olarak, Yargıtay'ın aksi yönde kararları olmakla birlikte, cinsel çağrışımlar uyandıran davranışların ve cinsel arzuları tatmin amacının arandığ cinsel taciz suçunun, kişilerin huzur ve sükûnunu bozma suçundan farklı bir suç tipi olduğu görülmektedir.

\section{GÜRÜLTÜ VE RAHATSIZ ETME KABAHATLERİ}

5326 say1lı Kabahatler Kanunu'nun 36. maddesinde gürültü kabahati,

"Başkalarının huzur ve sükûnunu bozacak şekilde gürültüye neden olan kişiye, elli Türk Lirası idari para cezası verilir.

Bu fiilin bir ticari işletmenin faaliyeti çerçevesinde işlenmesi halinde işletme sahibi gerçek veya tüzel kişiye bin Türk Lirasından beşbin Türk Lirasina kadar idari para cezası verilir.

Bu kabahat dolaylsiyla idari para cezasina kolluk veya belediye zabita görevlileri karar verir" şeklinde düzenlenmiştir.

suçundan da mahkûmiyetine karar verilmesi ..." (Yargıtay 14. CD. E. 2011/10192, K. 2012/1010, 08.02.2012) Aktaran: Yaşar - Gökcan - Artuç, s. 4090. Kanaatimizce somut olayda sanığın ifadelerinin cinsel taciz kapsamında görülmesi mümkün olmadığı gibi hukuki sorunun fikri içtima ile çözümlenmesi de doğru değildir. Zira tek bir fiille kanunun birden çok hükmünün ihlali anlamına gelen fikri içtimada, failin fiili her iki suça da vücut verebilmelidir. Ancak hem cinsel taciz hem de kişilerin huzur ve sükûnunu bozma suçunda failin özel kast ile hareket etmesinin aranması karşısında, fiilin hem cinsel taciz suçuna hem de kişilerin huzur ve sükûnunu bozma suçuna vücut verebilmesi yukarıda belirtilen kast kuralları uyarınca mümkün olamamalıdır.

162 "Sanı̆̆ın, katılanı cep telefonundan arayarak, 'Eve geleyim sen çay kahve ikram et' dediği, müştekinin kabul etmemesi üzerine 'Can Hastanesinin önüne gel, orada oturalım, çay kahve içelim' dediğinin belirtilmesi karşısında, sanı̆̆ın eyleminin kül halinde TCK'nın 105/1 maddesindeki cinsel taciz suçunu olușturup olușturmayacağının tartışmasız birakılması ..." (Yargitay 4. CD. E. 2012/13490, K. 2013/1080, 22.01.2013) Aktaran: Yașar - Gökcan - Artuç, s. 4079.

163 "Saat 13.00 siralarında evine doğru giden mă̆durenin arkasından arkadaşıyla birlikte gelip mağdureyi evine kadar ısrarla takip eden ve yazdiğı kağıdı mağdureye verip 'beni bu numaradan ararsın' şeklinde sırnaşıkça hareketlerde bulunan sanığın eylemi cinsel taciz suçunu oluşturduğu halde ...” (Yargitay 14. CD. E. 2011/7453, K. 2012/3116, 15.03.2012) Aktaran: Taner, s. 371. 
Kabahat olarak düzenlenmiş gürültü, gerçek kişiler tarafından icrai bir davranışla başkalarının huzur ve sükûnunu bozacak şekilde kasten işlenen bir fiildir. Gürültü kabahatinin uygulanması bakımından başkalarının huzur ve sükûnunu bozacak nitelikte gürültüye neden olunması gerekmektedir. Gürültünün nasıl gerçekleştirildiği veya gürültü yapılırken ne çeşit vasıtalar kullanıldığı önemli değildir. ${ }^{164}$ Yargıtay, özellikle kurusık1 tabancayla havaya ateş edilmesi olaylarında Kabahatler Kanunu'nun 36. maddesinin uygulama alanı bulacağına ${ }^{165}$ ve kurusıkı tabancanın TCK m. 170/1-c'deki "silah" kapsamına girmeyeceğine ${ }^{166}$ karar vermektedir. Ayrıca gürültü kabahatinde mağdur, gayrimuayyen sayıdaki kişiler iken; kişilerin huzur ve sükûnunu bozma suçunda mağdur belirli bir kişidir. ${ }^{167}$

${ }^{164}$ Yenerer Çakmut, s. 121.

165 "Sanığın rastgele havaya ateș ettiği ve gaz tabancası olarak nitelendirilen silahın 6136 sayll Kanun kapsamina giren silahlardan olup olmadiğ hususunda usulüne uygun bilirkişi incelemesi yaptırılarak söz konusu tabancanın gaz tabancası olduğunun anlaşılması halinde, ateşlenebilen bir silahın işlevine uygun ve sonuç doğurmaya elverişli bulunmayan kuru-sıkı olarak tabir edilen tabanca ile yerleşik yerde ateş etme şeklindeki eylemin, 5236 sayıl Kabahatler Kanunu'nun 36/1 madde ve fikrasında tanımı yapılan gürültüye sebep olma kapsamında olup idari yaptırımı gerektireceği ...” (Yargitay 8. CD. E. 2009/11718, K. 2011/10871, 12.10.2011) Erişim: http://www.kazanci.com/kho2/ibb/files/8cd-2009-11718.htm (04.04.2019)

166 "Sanığın kuru sikl tabancayla ateş etme eylemi, 5237 sayıl TCK 170/1-c madde ve fikrasında tanımı yapılan içinde ateşli silah ögesi bulunan suç tipine uygun bulunmadiğ eylemin 5326 sayll Kabahatler Kanununun 36. maddesinde düzenlenen... kabahati oluşturduğu ...” (Yargitay 8. CD. E. 2011/1392, K. 2011/941, 09.02.2011) Erişim: http://www.kazanci.com/kho2/ibb/files/8cd-2011-1392.htm (04.04.2019). “...silah niteliğinde bulunmayan kurusık tabanca ile havaya ateş etme eyleminin 5237 Sayll TCK.nun 170/1-c madde ve fikrasında tanımlanan ve içinde silah ögesi bulunan suç tipine uygun olmayacağ yapılan gürültüye neden olma kapsamında olup idari yaptırımı gerektireceği”' (Yargitay 8. CD. E. 2018/2646, K. 2018/10309, 03.10.2018) Erişim:http://www.kazanci.com/kho2/ibb/files/dsp.php?fn=8cd20182646.htm\&kw=kurus \%C4\%B1k\%C4\%B1\#fm (04.04.2019). Aynı yöndeki görüş için bkz. Zeki Hafızoğulları Muharrem Özen, Türk Ceza Hukuku Özel Hükümler Topluma Karşı Suçlar, B. 2, Ankara 2016, s. 13.

167 "Sanıkların, olay günü geceleyin saat 23.30 stralarında ilçe merkezindeki inşaatlarında herhangi bir kimseyi hedef almadan gürültü çıkartacak şekilde çalışmaya devam ederek çevreyi rahatsiz etmekten ibaret eylemlerinin, 5326 sayıl Kabahatler Kanunu'nun 36. maddesi kapsamında değerlendirilmesi gerekirken, belli bir kişiyi hedef alarak kasten işlenmesi mümkün olan ve olaya uygulanma imkânı bulunmayan 5237 sayılı TCK'nın 123. maddesinden hareketle yazılı şekilde şikâyetten vazgeçme nedeniyle 5271 sayılı CMK'nın 223/8. maddesi uyarınca davanın düşürülmesine karar verilmesi ...” (Yargıtay 2. CD. 5637-8990, 18.06.2007) Aktaran: Parlar - Hatipoğlu, s. 1937. 
Kabahatler Kanunu'nun 37. maddesinde ise rahatsiz etme kabahati, "Mal veya hizmet satmak için başkalarını rahatsız eden kişi, elli Türk Lirası idari para cezast ile cezalandırllır.

Bu kabahat dolaylsiyla idari para cezasl vermeye kolluk veya zabita görevlileri yetkilidir" şeklinde düzenlenmiştir.

$\mathrm{Bu}$ maddeyle mal veya hizmet satımı sırasında insanların taciz edilmesi ve benzeri hareketlerin gerçekleştirilmesi engellenmek istenmiştir. Fail, mal ve hizmet satmak amacıyla yüksek sesle bağırsa dahi gürültü değil; rahatsız etme kabahati ortaya çıkacaktır. Her çeşit seyyar satıcının, bayi temsilcilerinin, otogarda yer alan otobüs işletmecilerinin, kişilerin bulundukları yerlerde yüksek sesle mal veya hizmetlerini satmak amaciyla bağırmaları, kişilerin taşıdıkları pankart veya dövizlerle insanların yolunu keserek, onları sessiz dahi olsa taciz etmeleri, apartmanların içlerine girerek eşya, ürün veya hizmet satmak amacıyla kişilerin rahatsız edilmesi bu kabahate vücut verecektir. ${ }^{168}$

\section{E. GÜRÜLTÜYE NEDEN OLMA SUÇU}

Gürültüye neden olma suçu 5237 say1lı TCK m. 183/1'de, "İlgili kanunlarla belirlenen yükümlülüklere aykırl olarak, başka bir kimsenin sağllğının zarar görmesine elverişli bir şekilde gürültüye neden olan kişi, iki aydan iki yıla kadar hapis veya adli para cezası ile cezalandırllır" şeklinde düzenlenmiştir. Bu suç, TCK'nın "Topluma Karşı Suçlar” başlıklı üçüncü kısmının "Çevreye Karşı Suçlar" başlıklı ikinci bölümünde düzenlenmiştir. Gürültüye neden olma suçunun hukuki konusu, toplumun sağliklı bir çevrede yaşama hakkıdır. ${ }^{169}$ Dolayısıyla kişilerin huzur ve sükûnunu bozma suçundan farklı olarak gürültüye neden olma suçunun mağduru toplumdur. ${ }^{170}$ Yukarıda da ifade edildiği üzere, kişilerin huzur ve sükûnunu bozma suçunda belirli bir kişinin huzur ve sükûnunu bozmak maksadıyla seçimlik hareketler gerçekleştirilirken; gürültüye neden olma suçunda fail belirli bir kimseyi hedef almamaktadır. ${ }^{171}$

168 Yenerer Çakmut, s. 93.

${ }^{169}$ Handan Yokuş Sevük, "Gürültüye Neden Olma Suçu (TCK m. 183)”, in. Prof. Dr. Nur Centel'e Armağan, Y. 2013, C. 19, S. 2, s. 372.

${ }^{170}$ Gürülttüye neden olma suçunun belirli bir mağdurunun olmadığ 1 ve toplumda yaşayan herkesin bu suçun mağduru olabileceği yönündeki görüş için bkz. Yokuş Sevük, s. 372.

${ }^{171}$ Yokuş Sevük, s. 373. 
Bunun yanı sıra, gürültüye neden olma suçunda neden olunan gürültünün bir kimsenin sağllğının zarar görmesi bakımından elverişli olması aranırken; kişilerin huzur ve sükûnunu bozma suçunda başka bir kimsenin sağlı̆̆ının zarar görmesi açısından elverişlilik aranmamaktadır. Maddi unsur bakımından, kişilerin huzur ve sükûnunu bozma suçunda ısrar unsuru aranırken; gürültüye neden olma suçunda ısrar unsuru aranmamaktadır.

İki suç, manevi unsurların farklı olması yönünden de birbirinden ayrışmaktadır. Kişilerin huzur ve sükûnunu bozma suçunda, failin özel kastla hareket etmesi aranırken; gürültüye neden olma suçunun oluşabilmesi için genel kast yeterlidir. ${ }^{172}$

\section{SUÇUN MUHAKEMESI}

Kişilerin huzur ve sükûnunu bozma suçunun takibi, mağdurun şikâyetine bağlıdır. Şikâyet, işlenmiş bir suçtan dolayı, soruşturmaya başlanmasının ve ceza davası açılmasının suçtan zarar görenin şikâyetine bağlı tutulmasıdır. ${ }^{173}$ Bir muhakeme şartı olan şikâyetin somut olayda bulunmaması halinde ilgili suçtan soruşturma ve kovuşturma yapılamayacaktır. ${ }^{174}$ Kanunda ayrıca suçtan dolaylı zarar görenler için bir hüküm bulunmadığı takdirde, sadece suçtan doğrudan zarar gören pasif süjenin şikâyet hakkına sahip olduğunun kabul edilmesi gerekir. ${ }^{175}$ TCK m. 73'e göre şikâyet, fiilin ve failin öğrenilmesinden itibaren 6 ay içinde gerçekleşmelidir. ${ }^{176}$ Şikâyetin geri alınması ve sanığın geri almayı kabul etmesi halinde, TCK m. 73/4 ve CMK m. 223/8 uyarınca davanın düşmesine karar verilir. ${ }^{177}$

172 Kocasakal, s. 117.

${ }^{173}$ Devrim Güngör, 5237 ve 5271 Sayılı Kanunlar Işı̆̆ında Şikâyet Kurumu, B. 1, Ankara 2009, s. 35.

${ }^{174}$ Güngör, Şikâyet, s. 32; Nevzat Toroslu - Metin Feyzioğlu, Ceza Muhakemesi Hukuku, B. 9, Ankara 2012, s. 46.

175 Güngör, Şikâyet, s. 45.

${ }^{176}$ Kişilerin huzur ve sükûnunu bozma suçunun mütemadi suç olduğunu kabul eden yazarlar, şikâyet süresini temadinin sona erdiği tarihten itibaren başlatmaktadır. Bkz. Yaşar Gökcan - Artuç, s. 4075.

177 "Dosya kapsamına göre, sanığın telefonla müştekiyi rahatsız etmesi şeklinde belirlenen eyleminden dolayı mülga 765 sayıl TCK'nın 547. maddesi uyarınca cezalandırılmasına karar verilmiş ise de, 01.06.2005 tarihinde yürürlüğe giren 5237 sayıl TCK'nın 123. maddesi ile anılan suçun şikâyete tabi tutulması ve müştekinin 11.07.2005 tarihli celsede 
Madde yönünden yetkili mahkeme, 5235 sayılı Adli Yarg1 İlk Derece Mahkemeleri ile Bölge Adliye Mahkemelerinin Kuruluş, Görev ve Yetkileri Hakkında Kanun gereğince asliye ceza mahkemeleridir. Yer yönünden yetkili mahkeme ise suçun işlendiği yer mahkemesidir. Bu suç bakımından suçun işlendiği yer, maddede öngörülen seçimlik hareketlerin 1srar boyutunda ortaya çıtığı yer mahkemesidir.

Suçun soruşturulması ve kovuşturulması şikâyete bağlı olduğundan CMK m. 253 gereğince, bu suç hakkında uzlaştırma hükümleri uygulanacaktır. Uzlaştırmanın usulüne uygun biçimde yapılmadığı hallerde verilen kararlar kanun yolu incelemesinde bozma nedenidir. ${ }^{178}$

\section{YAPTIRIM}

TCK m. 123 gereğince kişilerin huzur ve sükûnunu bozma suçunu işleyen kimse, üç aydan bir yıla kadar hapis cezası ile cezalandırılır. Bu suç için adli para cezası öngörülmemiştir ve hakim yalnızca hapis cezasına hükmedebilir. ${ }^{179}$

Bu suç için dava zamanaşımı, TCK m. 66/1-e hükmü gereğince sekiz yıldır.

Kişilerin huzur ve sükûnunu bozma suçu için öngörülen üst sınırı bir yı1 olan hapis cezası, TCK m. 49/2 gereğince kısa süreli hapis cezasıdır. Bu nedenle kişilerin huzur ve sükûnunu bozma suçundan mahkûm olan bir kimsenin cezası, TCK m. 50 gereğince para cezasına veya seçenek yaptırıma çevrilebilir. Sanığa söz konusu madde uyarınca verilen hapis cezasının,

şikâyetinden vazgeçmiş olması karşısında söz konusu kanunun 73/4. maddesi gereğince düşme kararı verilmesi gerektiğinin nazara alınmaması ..." (Yargitay 2. CD. E. 2005/10476, K. 2005/24474, 09.11.2005) Erişim: http://www.kazanci.com/kho2/ibb/files/2cd-2005-10476.htm (04.04.2019)

178 "Sanığa atılı kişilerin huzur ve sükûnunu bozma suçu soruşturulması ve kovuşturulması şikâyete bağll suçlardan olduğu halde, mahkemece sanıktan uzlaşmayı kabul edip etmediğinin sorulmadiğı, sadece katılana uzlaşma önerisinde bulunulduğu ve katılanın uzlaşmayı kabul etmediğine ilişkin beyanıyla yetinildiği anlaşılmakla, 5271 sayılı Ceza Muhakemesi Kanunu'nun 253 ve 254. maddeleri uyarınca usulüne uygun uzlaş̧ırma işlemi yapılmadan eksik kovuşturma ile yazılı şekilde hüküm kurulması ...” (Yargitay 2. CD. E. 2008/18903, K. 2009/17759, 02.04.2009) Aktaran: Yaşar - Gökcan - Artuç, s. 4093.

179 “5237 sayılı TCK'nın 123/1. maddesinde yaptırım olarak üç aydan bir yıla kadar hapis cezası öngörüldüğ̈̈ halde, sanı̆̆a kişilerin huzur ve sükûnunu bozma eylemi nedeniyle mahkemece doğrudan adli para cezası verilmesi ...” (Yargitay 2. CD. E. 2008/14948, K. 2008/20103, 25.11.2008) Aktaran: Yaşar - Gökcan - Artuç, s. 4074, dn. 2490. 
seçenek yaptırımlardan birine çevrilmemesi halinde, verilen bu ceza TCK m. 51 gereğince ertelenebilir. Ayrıca suç için öngörülen hürriyeti bağlayıcı ceza iki yılın altında olduğundan, diğer koşulları da mevcutsa CMK m. 231/5 uyarınca, hükmün açıklanmasının geri bırakılmasına karar verilebilir.

Hakim somut olayda temel cezayı belirlerken, TCK m. 61'de yer alan hususları göz önünde bulunduracaktır. Ancak bu suçta failin huzur ve sükûnu bozma maksadiyla hareket etmesinin aranmas1, TCK m. 61/1-g uyarınca hapis cezasının alt sınırdan uzaklaşılarak üst sınırdan verilmesi için tek gerekçeyi oluşturmamalıdır. ${ }^{180}$

\section{SONUÇ}

Kişilerin yaşam haklarına bağlı olarak, huzurlu biçimde yaşamalarını, bedensel ve ruhsal dengelerini koruma altına alabilmek amaciyla ulusal hukuklarda ve uluslararası düzenlemelerde pek çok düzenleme bulunmaktadır. Çalışma konumuz olan kişilerin huzur ve sükûnunu bozma suçu da bu menfaatin cezai açıdan himayesini sağlamaktadır. "Hürriyete Karş1 Suçlar" bölümünde düzenlenen bu suçun fiil unsurunda, üç farklı seçimlik hareket öngörülmüş; ancak "hukuka aykırı başka bir davranışta bulunmak" ifadesiyle suça vücut verebilecek davranışlar sınırlı sayıda tutulmamıştır. $\mathrm{Bu}$ durumun, ceza hukukunun temel prensiplerinden olan kanunilik ilkesiyle bağdaşmadığı düşünülmektedir. Uygulanma sıklığı da göz önüne alındığında, hangi davranışların bu suça vücut vereceğinin madde metninde açıkça belirtilmesi isabetli olacaktır. Suçun fiil unsurunda yer alan ısrarın her somut olay bakımından gerçekleşip gerçekleşmediğinin araştırılması gerekmektedir.

$\mathrm{Bu}$ suçun benzer suçlardan ayrımında, Kanun'da aranan özel kastın önem arz ettiği belirtilmelidir.

Herhangi bir nitelikli halin öngörülmediği bu suçun, teorik açıdan teşebbüse elverişli olduğu, ancak bunun çok sinırlı durumlarda gerçekleşebileceği ifade edilmelidir. Zira suçun gerçekleşmesi için ısrarın aranması karşısında; suçun elverişli hareketlerle icrasına başlanmasından sonra elde olmayan nedenlerle suçun tamamlanamaması halinde suçun teşebbüste kaldığ 1 kabul edilmelidir.

${ }^{180}$ Gülşen, s. 17. 
İştirak açısından özellik arz etmeyen bu suçun zincirleme suç biçiminde işlenebilmesi mümkündür. Ancak suçun varlığ için 1srarın aranması karşısında, seçimlik hareketlerin farklı zamanlarda birden çok defa gerçekleştirmesi halinde suç tekliğini koruyacaktır.

Kişilerin huzur ve sükûnunu bozma suçunun; cinsel taciz suçundan, gürültü ve rahatsız etme kabahatinden ve mülga TCK'daki düzenlemeden farklılaştığı görülmektedir. Karşılaştırmalı hukuktaki düzenlemelerin aksine stalking, hukukumuzda bağımsız bir suç olarak düzenlenmemiştir. Ancak diğer koşulların da bulunması halinde stalking kapsamındaki fiillerin; kişilerin huzur ve sükûnunu bozma, cinsel taciz, hakaret veya tehdit suçlarına vücut verebileceği göz önünde bulundurulmalıdır. 


\section{KAYNAKÇA}

Artuk Mehmet Emin - Gökcen Ahmet - Yenidünya Ahmet Caner: Ceza Hukuku Genel Hükümler, B. 9, Ankara 2015.

Centel Nur - Zafer Hamide - Çakmut Özlem: Türk Ceza Hukukuna Giriş, B. 10, İstanbul 2017.

Demirbaş Timur: Ceza Hukuku Genel Hükümler, B. 6, Ankara 2009.

Ekici Şahin Meral: Ceza Hukukunda Rıza, B. 1, İstanbul 2012. (Rıza)

Ekici Şahin Meral: "Kişilerin Huzur ve Sükûnunu Bozma Suçu (TCK m. 123)”, in. CHD, S. 23, 2013, s. 21-52. (Huzur ve Sükûnunu)

Erdoğan Mustafa: İnsan Hakları Teorisi ve Hukuku, B. 1, Ankara 2007.

Erem Faruk: Türk Ceza Kanunu Şerhi Özel Hükümler, C. 2, B. 1, Ankara 1993. (C. 2)

Erem Faruk: Türk Ceza Kanunu Şerhi Özel Hükümler, C. 3, B. 1, Ankara 1993. (C. 3)

Garner Bryan: Black’s Law Dictionary, Second Pocket Edition, 2001.

Gökcen Ahmet: "Hürriyete Karşı Suçlar”, s. 1-37. (Erişim: www.cezabb.adalet.gov.tr/makale/117.doc (04.04.2019)

Gülşen Recep: "Kişilerin Huzur ve Sükûnunu Bozma Suçu”, in. Zirve Üniversitesi Hukuk Fakültesi Dergisi, S. 1, 2012, s. 5-20.

Güngör Devrim: Ceza Hukukunda Fiil Üzerinde Hata, B. 1, Ankara 2007. (Hata)

Güngör Devrim: 5237 ve 5271 Sayılı Kanunlar Işı̆̆ında Şikâyet Kurumu, B. 1, Ankara 2009. (Şikâyet)

Hafızoğulları Zeki - Özen Muharrem: Türk Ceza Hukuku Genel Hükümler, B. 8, Ankara 2015. (Genel Hükümler)

Hafızoğulları Zeki - Özen Muharrem: Türk Ceza Hukuku Özel Hükümler Kişilere Karşı Suçlar, B. 5, Ankara 2016. (Kişilere Karşı)

Hafızoğulları Zeki - Özen Muharrem: Türk Ceza Hukuku Özel Hükümler Topluma Karşı Suçlar, B. 2, Ankara 2016. (Topluma Karşı) 
Hakeri Hakan: Ceza Hukukunda İhmal Kavramı ve İhmali Suçların Çeşitleri, B. 1, Ankara 2003.

Katoğlu Tuğrul: Ceza Hukukunda Hukuka Aykırılık, B. 1, Ankara 2003.

Kocasakal Ümit: "Kişilerin Huzur ve Sükûnunu Bozma Suçu (TCK 123)”, in. ABD., Y. 2015, S. 2, s. 110-146.

Kurt Gülşah: "5237 Sayılı Türk Ceza Kanununda Cinsel Taciz Suçu”, in. Uğur Alacakaptan'a Armağan, C. 1, B. 1, İstanbul 2008, s. 507-525.

Meydan Nihat - Yapal Fadime: İçtihatlı Türk Ceza Kanunu, C. 2, B. 1, İstanbul 2004.

Özbek Veli Özer - Kanbur Mehmet Nihat - Doğan Koray - Bacaksız Pınar - Tepe İlker: Türk Ceza Hukuku Özel Hükümler, B. 5, Ankara 2013.

Parlar Ali - Hatipoğlu Muzaffer: Açıklamalı ve Yeni İçtihatlarla 5237 Sayılı Türk Ceza Kanunu Yorumu, C. 2, B. 3, Ankara 2010.

Şen Ersan: Yeni Türk Ceza Kanunu Yorumu, C. 1, B. 1, İstanbul 2006.

Taner Fahri Gökçen: Türk Ceza Hukukunda Cinsel Özgürlüğe Karşı Suçlar, B. 1, Ankara 2013.

Tezcan Durmuş - Erdem Mustafa Ruhan - Önok Murat: Teorik ve Pratik Ceza Özel Hukuku, B. 10, Ankara 2013.

Toroslu Nevzat: Ceza Hukuku Genel Kısım, B. 14, Ankara 2009.

Toroslu Nevzat - Feyzioğlu Metin: Ceza Muhakemesi Hukuku, B. 9, Ankara 2012.

Türkmen Ahmet: "Yeni Bir Hukuki Olgu Olarak Israrlı Takip ve Taciz (Stalking) ve Bunun Türk Medeni Hukuku Bakımından Değerlendirilmesi”, in. DEÜHFD, C. 11, İzmir 2010, s. 1387-1434.

Yalçın Sancar Türkan: Müteselsil Suç, Ankara 1995.

Yaşar Osman - Gökcan Hasan Tahsin - Artuç Mustafa: Yorumlu Uygulamalı Türk Ceza Kanunu, C. 3, B. 2, Ankara 2014.

Yaşar Osman: Yeni İçtihatlarla Uygulamalı ve Yorumlu Ceza Muhakemesi Kanunu, C. 2, B. 5, Ankara 2011. 
Yenerer Çakmut Özlem: Kişilerin Huzur ve Sükûnunu Bozma ve Gürültüye Neden Olma Suçları, B. 1, İstanbul 2014.

Yenisey Feridun - Plagemann Gottfried: Alman Ceza Kanunu Strafgesetzbuch (StGB), B. 2, İstanbul 2015.

Yokuş Sevük Handan: “Gürültüye Neden Olma Suçu (TCK m. 183)”, in. Prof. Dr. Nur Centel'e Armağan, Y. 2013, C. 19, S. 2, s. 363-379.

\section{Yararlanılan İnternet Siteleri:}

http://www.ceza-bb.adalet.gov.tr/

http://www.kazanci.com/

http://www.tdk.gov.tr/ 


\section{KISALTMALAR}

$\begin{array}{ll}\text { ABD. } & \text { : Ankara Barosu Dergisi } \\ \text { AIHS } & \text { : Avrupa İnsan Hakları Sözleşmesi } \\ \text { B. } & : \text { Baskı } \\ \text { bkz. } & : \text { Bakınız } \\ \text { C. } & : \text { Cilt } \\ \text { CD. } & : \text { Ceza Dairesi } \\ \text { CGK } & : \text { Ceza Genel Kurulu } \\ \text { CHD } & : \text { Ceza Hukuku Dergisi } \\ \text { CMK } & : \text { Ceza Muhakemesi Kanunu } \\ \text { DEÜHFD } & : \text { Dokuz Eylül Üniversitesi Hukuk Fakültesi Dergisi } \\ \text { dn. } & : \text { Dipnot } \\ \text { E. } & : \text { Esas } \\ \text { İHEB } & : \text { İnsan Hakları Evrensel Beyannamesi } \\ \text { in. } & : \text { İçinde } \\ \text { K. } & : \text { Karar } \\ \text { m. } & : \text { Madde } \\ \text { R.G. } & : \text { Resmi Gazete } \\ \text { s. } & : \text { Sayfa } \\ \text { S. } & : \text { Sayı } \\ \text { TCK } & : \text { Türk Ceza Kanunu } \\ \text { vb. } & : \text { Ve Benzeri } \\ \text { vd. } & : \text { Ve Devamı } \\ \text { Y. } & : \text { Yıl } \\ \end{array}$

